\title{
Indoor air quality in schools and its relationship with children's respiratory symptoms
}

\author{
Joana Madureira a, *, Inês Paciência a , João Rufo a , Elisabete Ramos ${ }^{\text {b, c }}$, Henrique Barros ${ }^{\text {b, c }}$, \\ João Paulo Teixeira b, d, Eduardo de Oliveira Fernandes ${ }^{a}$ \\ a Institute of Science and Innovation on Mechanical Engineering and Industrial Management, Rua Dr. Roberto Frias, $4200-465$ Porto, Portugal \\ ${ }^{\mathrm{b}}$ Public Health Institute, University of Porto, Rua das Taipas 135, 4050-600 Porto, Portugal \\ c Department of Clinical Epidemiology, Predictive Medicine and Public Health, University of Porto Medical School, Alameda Professor Hernâni Monteiro, \\ 4200-319 Porto, Portugal \\ d Environmental Health Department, National Institute of Health, Rua Alexandre Herculano, 321, 4000-055 Porto, Portugal
}

\section{H I G H L I G H T S}

- Indoor air measurement campaigns in 73 classrooms from 20 public primary schools.

- Children health information obtained using a questionnaire and clinical tests.

- Relationships between IAQ and children's respiratory symptoms.

- Even at low levels indoor air pollutants were related with the respiratory symptoms.

\section{A R T I C L E I N F O}

\section{Article history:}

Received 25 May 2015

Received in revised form

17 July 2015

Accepted 19 July 2015

Available online 26 July 2015

\section{Keywords:}

Schools

Indoor air quality

Particulate matter

Respiratory symptoms

Asthma

\begin{abstract}
A B S T R A C T
A cross-sectional survey was conducted to characterize the indoor air quality (IAQ) in schools and its relationship with children's respiratory symptoms. Concentrations of volatile organic compounds (VOC), aldehydes, $\mathrm{PM}_{2.5}, \mathrm{PM}_{10}$, carbon dioxide, bacteria and fungi were assessed in 73 classrooms from 20 public primary schools located in Porto, Portugal. Children who attended the selected classrooms $(n=1134)$ were evaluated by a standardised health questionnaire completed by the legal guardians; spirometry and exhaled nitric oxide tests.

The results indicated that no classrooms presented individual VOC pollutant concentrations higher than the WHO IAQ guidelines or by INDEX recommendations; while $\mathrm{PM}_{2.5}, \mathrm{PM}_{10}$ and bacteria levels exceeded the WHO air quality guidelines or national limit values. High levels of total VOC, acetaldehyde, $\mathrm{PM}_{2.5}$ and $\mathrm{PM}_{10}$ were associated with higher odds of wheezing in children. Thus, indoor air pollutants, some even at low exposure levels, were related with the development of respiratory symptoms. The results pointed out that it is crucial to take into account the unique characteristics of the public primary schools, to develop appropriate control strategies in order to reduce the exposure to indoor air pollutants and, therefore, to minimize the adverse health effects.
\end{abstract}

(c) 2015 Elsevier Ltd. All rights reserved.

\section{Introduction}

Because of their immature immune and respiratory system, inferior body mass index and breathing pattern children are more susceptible to the effects of air pollution than adults. Asthma and allergy are two of the most prevalent diseases in children (Pearce

\footnotetext{
* Corresponding author.

E-mail address: jmadureira@inegi.up.pt (J. Madureira).
}

et al., 2000). Moreover, both diseases are often associated being asthma the culminant disease resultant from the atopic march (Bantz et al., 2014). There is evidence of the increased prevalence of asthma and allergies over the recent decades, especially in developed countries, among children (WHO, 2007; Lotvall et al., 2009). It has been reported that more than a third of children in Europe has had bronchial asthma or allergy (Asher et al., 1998).

The aforementioned increase is assumed to be multi-factorial and to result from complex interactions between genetic predisposition and environmental factors. Among the latter, indoor air 
pollution has assumed a particular major relevance (Masoli et al., 2004). Indoor air has been the focus of scientists during the last decade, specifically due to the fact that people spend most of their time indoors, especially at home and in school.

Indoor air quality (IAQ) is determined by a combination of numerous pollutants originated from a wide spectrum of pollution sources, with all of them having specificities associated to the place, the climate and the culture: the local ambient air, the buildings characteristics and the indoor activities (Oliveira Fernandes et al., 2008). The IAQ in schools is generically characterized by a complexity of various pollutants namely volatile organic compounds (VOC), particulate matter, aldehydes, bacteria and molds (Madureira et al., 2009, 2012).

Indoor air pollutants can cause or contribute to short-term and long-term health problems (Clausen et al., 2009; Simoni et al., 2010; Annesi-Maesano et al., 2013). Moreover, indoor air pollutants can provoke discomfort and reduce school attendance and productivity (Mendell and Heath, 2005). Despite the large population of primary schoolchildren, only a few studies regarding IAQ in Portuguese primary schools have been undertaken (Madureira et al., 2009; Martins et al., 2012; Pegas, 2012). Often a specific pollutant, e.g. particulate matter or bioaerosols, or a combination of pollutants, are addressed, and just a few studies, have used objective measurements of IAQ and health indicators, such as spirometry and exhaled nitric oxide (eNO).

In order to improve the indoor environmental conditions in schools, which represent one of the major contributor of children's total exposure (Bluyssen, 2014), and, thus, to limit exposures that may cause or contribute to asthma, allergy and other respiratory symptoms in children, the main objective of this work was to conduct a comprehensive characterization of the IAQ in schools and its relationship with children's respiratory symptoms.

These findings are of relevance to public health due to the very large population of exposed school children since the attendance in primary schools is compulsory and asthma and allergy are very common diseases in childhood. These data may be useful for assessing the health effects of exposure, for understanding the underlying mechanisms and for implementing preventive policies in terms of standards and guidelines.

\section{Material and methods}

Due to budget and time limitations, a cross-sectional survey was carried out in 20 public primary schools located in Porto, North of Portugal at the sea shore $\left(41^{\circ} \mathrm{N}, 8 \mathrm{~W}\right)$ featuring a Mediterranean climate with moderate temperatures and rainy weather in the winter season (Fig. 1S, in the Supplementary Material).

The number of schools was defined based on the estimated sample size of children to study the relation between IAQ and asthma, allergy and respiratory symptoms. In regard to the figures obtained in recent studies in Portugal, the prevalence of asthma in children is approximately $10 \%$ while it is estimated that $10 \%$ of nonasthmatic children have symptoms and that the exposure to poor indoor air leads to a two times higher risk of having symptoms (Falcão et al., 2008). Within these premises, a sample of 1600 children was established. Thus, assuming 20 children per room (Direção-Geral de Estatísticas da Educação e Ciência, 2014) and 4 classrooms per school, a sample size of 20 schools was used to give sufficient confidence. Thus, the 20 (38\%) schools with the highest number of students were selected from a total of 53 public primary schools (Table 1S).

Depending on the size of the school, two to four classrooms per school, comprised of 8-10 year old children, were simultaneously investigated. The preference was for classrooms with high density occupation as well as full weekly occupation time by the same class, and, if possible, at different floor levels. As a result, a total of 73 classrooms were selected. No classrooms had mechanical ventilation systems; opening windows was the only way to renovate the air indoors. In the winter season, the windows were closed due to the outdoor weather conditions and/or due to the fact that heating systems were turned on.

The study was conducted respecting the Declaration of Helsinki and was approved by the Ethics Committee of the University of Porto (22/CEUP/2011). Written informed consent was obtained from parents or legal guardians of the children.

\subsection{Indoor air quality assessment}

School visits and air sampling were conducted in the winter seasons, from November to March, during years 2011-2013. Measurements of VOC, aldehydes, $\mathrm{PM}_{2.5}, \mathrm{PM}_{10}$, bacteria, fungi, temperature and relative humidity levels were conducted simultaneously both indoors and outdoors during a 5-day period (school week, from Monday morning until Friday afternoon). The air samplings were performed during regular daily activities, except for VOC and aldehydes, and under representative conditions of occupancy and use of the classrooms.

\subsection{Air sampling and analysis}

Safe and childproof sampling locations were selected complying ISO 16000-1 (2004). Indoor samples were collected near occupants' breathing zone (approximately $0.7-1.5 \mathrm{~m}$ above the floor). Sampling locations were no closer than $1 \mathrm{~m}$ to a wall, window, door, or an active heating system. Furthermore, the indoor sampling locations were selected as far away as possible from the blackboard, when applicable. The sampling process was supervised by a researcher who recorded information regarding classroom occupancy, ventilation and occupant behaviour and activities. Outdoor samples were obtained concurrently to indoor air sampling whenever possible no closer than $1 \mathrm{~m}$ from the building at heights of $1-2 \mathrm{~m}$ above the ground.

Volatile organic compounds were collected using stainless-steel sampling tubes containing Tenax ${ }^{\circledR}$ TA (60/80 mesh). Tenax tubes were transferred to the laboratory and thermally desorbed (Dani STD 33.50) and quantified using a non-polar column by gas chromatography (Agilent Technologies 6890N) coupled to a mass spectrometry detector (Agilent Technologies 5973), according to ISO 16000, part 6 (2011). Total VOC (TVOC) concentration was quantified using the toluene response factor, and concentrations were calculated as the sum of VOC eluting between hexane and hexadecane (included), expressed as toluene. The indoor and outdoor air sampling covered a 5-day period (school week, from Monday morning until Friday afternoon). To control contamination during transport and sampling, a field blank was employed in every school. All samples were taken in duplicate to verify the reproducibility of measurements. Aldehydes (formaldehyde and acetaldehyde) were sampled by Radiello ${ }^{\circledR}$ passive devices (RAD 165, Sigma Aldrich) during a school week (from Monday morning until Friday afternoon) and determined using isocratic reverse phase High Performance Liquid Chromatography (HPLC) with a UV detector operated at $360 \mathrm{~nm}$, according to ISO 16000-4 (2011). Aldehydes were identified and quantified by comparison of their retention times and peak areas with those of standard solutions. Each cartridge was sealed after sampling and brought back to the laboratory where it was stored in a refrigerator $\left(<4{ }^{\circ} \mathrm{C}\right)$. As an internal quality control, duplicate samplings were collected in one school per each three. Field blanks were collected and analysed to assess possible contamination through the sample collection and analysis process. The detection limits were $0.075 \mu \mathrm{g} / \mathrm{m}^{3}$ for 
formaldehyde and $0.178 \mu \mathrm{g} / \mathrm{m}^{3}$ for acetaldehyde.

Portable TSI DustTrak DRX photometers (model 8533; TSI Inc.) were used for the assessment of $\mathrm{PM}_{2.5}$ and $\mathrm{PM}_{10}$ concentrations. This equipment measures particles with a laser photometer based on light scattering principle. The measuring range of the equipment is $1-150 \times 10^{3} \mu \mathrm{g} / \mathrm{m}^{3}$ with accuracy of $\pm 0.1 \%$ of reading of $1 \mu \mathrm{g} / \mathrm{m}^{3}$, and it operates with a flow rate of $3.0 \mathrm{l} / \mathrm{min}$ using a built-in diaphragm pump powered by an internal battery. Instruments were installed inside each classroom and were set to continuously measure during at least one school day ( $8 \mathrm{~h}$, avoiding Mondays and Fridays). Logging intervals were set to $1 \mathrm{~min}$ between each sample. Similarly to the indoor sampling, another TSI DustTrak DRX photometer was also used for the assessment of outdoor $\mathrm{PM}_{2.5}$ and $\mathrm{PM}_{10}$ concentrations. Instruments were installed outside in the school playground, at a high of $1-1.2 \mathrm{~m}$ to simulate the children's breathing zone, protected from rain and carefully leaving the inlet uncovered to not disturb the sampling. The instrument was set to continuously measure the outdoor $\mathrm{PM}_{2.5}$ and $\mathrm{PM}_{10}$ during at least one school day ( $8 \mathrm{~h}$, avoiding Mondays and Fridays). Logging intervals were also set to $1 \mathrm{~min}$ between each sample. The monitors are zeroed automatically using the external zeroing module. By zeroing the monitors during sampling, the effect of zero drift is minimized. Meanwhile, the two available photometers were calibrated externally once per year at the factory.

Bacterial and fungal air samples were obtained using a singlestage microbiological air impactor (AirIdeal ${ }^{\mathrm{TM}}$, bioMérieux SA) according to the NIOSH Method 0800 (1998) and EN 13098 (2000). Tryptic Soy Agar (TSA) (supplemented with $0.25 \%$ cicloheximide) and Malt Extract Agar (MEA) (supplemented with 1\% of chloramphenicol) were used as culture media for bacteria and fungi, respectively. Air was drawn through the sampler at $100 \mathrm{l} / \mathrm{min}$ and sequential duplicate air samples (duplicates of 100 and $250 \mathrm{~L}$ ) were collected both indoors and outdoors between 9.30 a.m. and 12.00 a.m. For each sampling day, agar media blanks per culture media, were taken into the field. The air sampler was always cleaned between sample collections with cotton wipes wetted with isopropyl alcohol. After sampling, the agar media plates were sealed, marked and transported to the laboratory in a thermal bag for incubation. To quantify the bacterial and fungal concentrations, samples were incubated at $37 \pm 1^{\circ} \mathrm{C}$ for $48 \pm 3 \mathrm{~h}$ and at $25 \pm 3^{\circ} \mathrm{C}$ for $72 \pm 3 \mathrm{~h}$, respectively (European Standards, 2000). Quantification of bacteria and fungi levels was performed by naked eye count in accordance to the methodologies expressed in ISO 4833: 2013 (2013) and EN 13098: 2000 (2000). The number of colonies recovered on the air-sample plates was adjusted using a positivehole correction factor, and the results were expressed as number of colony forming units per cubic meter of air $\left(\mathrm{CFU} / \mathrm{m}^{3}\right)$. The correction factor was based on the Fellers law (Andersen, 1958). The quantification limit is established as $10 \mathrm{CFU}$ per plate.

Carbon dioxide $\left(\mathrm{CO}_{2}\right)$, temperature and relative humidity levels were recorded concurrently with the other air parameters (both indoors and outdoors) using an IAQ-CALC monitor (model 7545, TSI, Inc.). The equipment combined an infrared non-dispersive sensor for $\mathrm{CO}_{2}$, an thermistor for measuring temperature in a range from 0 to $60{ }^{\circ} \mathrm{C}$ with an accuracy of $\pm 0.6{ }^{\circ} \mathrm{C}$, and a thin-film capacitive sensor for relative humidity (range of $5-95 \%$ relative humidity; accuracy $\pm 3.0 \%$ relative humidity). Measurements were conducted during one school week with a time step of 5 min during the investigation week both indoors and outdoors.

\subsection{Health-related data collection}

The child health data was obtained using a questionnaire completed at home by legal guardians, based on the ISAAC (International Study of Asthma and Allergies in Childhood) questionnaire; and by a clinical examination including spirometry and eNO tests performed at school by trained health professionals. Lung function measurement by spirometry permits the discrimination of participants with respiratory symptoms and is invaluable as a screening test for general respiratory health (Mortimer et al., 2003; Miller et al., 2005). Exhaled nitric oxide is considered as a readout of certain aspects of airway inflammation, particularly in atopic asthma. Exhaled nitric oxide was used as a non-invasive marker of asthmatic inflammation and has several characteristics (instantaneous, non-invasive, repeatable, safe) that make it ideally suited for children (Prieto, 2002; Hatziagorou and Tsanakas, 2007).

\subsubsection{Questionnaire}

The questionnaire was filled in by legal guardians and comprised questions about respiratory/allergic health of the child; current symptoms/diagnosis; environmental tobacco smoke exposure, perinatal information, dietary habits, socio-economic characteristics and building characteristics of the home, in particular the child's bedroom (e.g. outdoor traffic pollution, dampness, floor and wall coverings, cooking fuel types; air conditioning).

The health outcomes analysed in the current study are based on the following questions: (i) wheeze ( $<12$ months): "In the past 12 months, has your child had wheezing or whistling in the chest?"; (ii) wheeze (<30 days): "In the past 30 days, has your child had wheezing or whistling in the chest?"; (iii) ever nasal allergy: "Has your child ever had nasal allergies, including hay fever?"; (iv) cough episodes: "Does your child have cough on most days (four or more days per week) apart from common colds?”; and (iv) phlegm episodes: "Does your child have phlegm on most days (four or more days per week) apart from common colds?".

\subsubsection{Clinical examination}

The clinical tests were performed at school during a normal school period following standardised procedures, in one day of the week of the IAQ measurements in the classrooms. All participant children were invited to measure weight, height and lung function. Exhaled nitric oxide was measured in a sub-sample of five children from each classroom. These children were randomly selected from the total participants.

Body weight was measured using a digital scale-Tanita (Tanita ${ }^{\circledR}$ TBF-300, Tanita Corporation of America, Inc., Illinois, USA) (in kilograms, to the nearest tenth), and height was measured (in centimetres, to the nearest tenth) using a portable stadiometer (SECA ${ }^{\circledR}$ 214). Both were measured with the child upright and standing without shoes. Then, the body mass index (BMI) was calculated [weight $(\mathrm{kg}) / \mathrm{m}^{2}$ ].

Lung function was measured using a spirometer (ML3500, MicroLab ${ }^{\circledR}$ ). All spirometry tests were performed according to American Thoracic Society/European Respiratory Society guidelines (1995) and the indexes measured or derived from lung function were referenced to predicted values (\%): forced vital capacity (FVC), forced expiratory volume in $1 \mathrm{~s}\left(\mathrm{FEV}_{1}\right), \mathrm{FEV}_{1} / \mathrm{FVC}$ ratio and forced expiratory flow $25-75 \%\left(\mathrm{FEF}_{25-75 \%}\right)$. In brief, immediately following a full inhalation, the children seals his/her lips around the mouthpiece and blasts the air out as fast as possible until the lungs are absolutely empty. Demonstration to the children of the procedure and the maximal effort required was performed before starting, and the best of three technically acceptable tests was considered the final result.

The levels of eNO were measured according to the ATS/ERS guidelines (2005) with the handheld device NIOX MINO system (Aerocrine, Stockholm, Sweden) with a detection limit of $5 \mathrm{ppb}$. The analyser provides online continuous measurement of nitric oxide. After children exhaled residual volume, they inserted the mouthpiece, inhaled nitric oxide free air from the apparatus to the total 
lung capacity and then exhaled for $10 \mathrm{~s}$ at a constant flow rate of $50 \mathrm{ml} / \mathrm{s}$. The end point of measurement occurred when a plateau for at least $2 \mathrm{~s}$ was observed. A visual feedback helped the children achieve the desired expiratory flow of $50 \mathrm{ml} / \mathrm{s}( \pm 10 \%)$.

\subsection{Participants}

A total of 1639 children were invited to participate in the survey. One hundred and eighty one (11.0\%) parents refused and 324 (19.8\%) did not return the signed consent form and parent questionnaire and were, therefore, considered as refusals (participation rate of $69.2 \%$ ). Out of 1099 children (mean age $8.6 \pm 0.7$ years) who participated in parents questionnaire, for the detailed analyses, 121 children were excluded due to with missing information on at least one of the following outcomes (ISAAC questions): wheeze $(<12$ months), wheeze ( $<30$ days), ever nasal allergy, cough episodes and phlegm episodes. The final sample was 978 children ( 508 girls) to study respiratory symptoms; 761 (392 girls) concerning lung function and 318 (165 girls) regarding the eNO test.

\subsection{Statistical analysis}

Shapiro-Wilk test was used for normality testing. The distribution of all indoor air parameters were skewed; thus they were described by median, 25th percentile (P25) and 75th percentile (P75). $\mathrm{PM}_{2.5}, \mathrm{PM}_{10}$, temperature and relative humidity levels were calculated from the data collected during teaching periods; while data of the VOC and aldehydes are reported for the school week under observation. These parameters were categorized into three classes according to the tertiles of exposure. Concentrations of VOC below the detection limits were excluded from the statistical analyses. It is noteworthy that in order to correctly explore the relationship between indoor and outdoor, the data used for the $\mathrm{I} / \mathrm{O}$ ratios analysis were those collected during the same period from indoor data. Kruskal-Wallis test was used to compare continuous variables.

To evaluate the association between indoor air exposure and respiratory symptoms, odds ratio (OR) and respective 95\% confidence intervals (95\% CI), were computed, using logistic regression models. Adjustments have been made for age (continuous variable in years), sex, mother's education level (categorical variable measured as the number of successfully completed years of formal schooling: $0-6$ years; $7-9$ years; $10-12$ years and $\geq 13$ years), BMI (continuous variable), relative humidity and temperature (both as continuous variable).

Statistical analyses were performed using SPSS Statistics version 19. A p-value below 0.05 was considered statistically significant.

\section{Results}

The summary of the indoor measurements taken in the 73 classrooms is presented in Table 1. Tables 2S and 3S, in the Supplementary Material, provides the outdoor measurements and indoor/outdoor ratio for air parameters, respectively.

The median TVOC concentration was $140.3 \mu \mathrm{g} / \mathrm{m}^{3}$ $\left(\mathrm{P} 25-\mathrm{P} 75=85.5-198.4 \mu \mathrm{g} / \mathrm{m}^{3}\right)$. Among the indoor VOC concentrations, D-limonene presented the highest levels $\left(23.1 \mu \mathrm{g} / \mathrm{m}^{3}\right)$ followed by toluene $\left(6.37 \mu \mathrm{g} / \mathrm{m}^{3}\right)$; while benzene, $\mathrm{m} / \mathrm{p}$-xylene, oxylene, $\alpha$-pinene, trichloroethylene, tetrachloroethylene, naphthalene and styrene had median levels lower than $5 \mu \mathrm{g} / \mathrm{m}^{3}$. Indoor levels of individual VOC were higher than outdoor levels being only significant for D-limonene $\left(23.1 \mu \mathrm{g} / \mathrm{m}^{3}\right.$ vs. $\left.2.05 \mu \mathrm{g} / \mathrm{m}^{3}, p=0.001\right)$ (Table 2S) and as expected, indoor concentrations usually exceeded outdoor levels; being significant only for D-limonene $(p=0.001)$ (Table 3S). The high indoor/outdoor ratios $(\mathrm{I} / \mathrm{O}>6)$ for $\mathrm{D}$-limonene, formaldehyde and acetaldehyde, and the moderate I/O ratio $(\sim 2)$ for TVOC and toluene suggest that indoor sources are the main origin for these VOC. In contrast, the I/O ratio for benzene ( 0.84 ) indicates that outdoor sources were the primary contributors (Table 3S). No classrooms presented individual VOC pollutant concentrations higher than the WHO IAQ guidelines (WHO, 2010) or the INDEX recommendations (Kotzias et al., 2005). Classrooms with graphic art activities (e.g. painting) had some of the highest levels measured for certain VOC (e.g., toluene and naphthalene, respectively).

The lowest aldehyde levels were observed for acetaldehyde (Table 1). The median values of formaldehyde levels were lower than the guidelines values established by the WHO (2010) and the EU-INDEX project (Kotzias et al., 2005); being significantly higher than those measured outdoors ( 17.5 vs. $2.74 \mu \mathrm{g} / \mathrm{m}^{3}, p<0.05$ ). The indoor median concentration of $\mathrm{PM}_{2.5}$ and $\mathrm{PM}_{10}$ in all classrooms exceed the $25 \mu \mathrm{g} / \mathrm{m}^{3}$ and $50 \mu \mathrm{g} / \mathrm{m}^{3}$ guideline values suggested by WHO air quality guidelines for a sampling period of $24 \mathrm{~h}$ (WHO, 2005). Outdoor levels of $\mathrm{PM}_{2.5}$ and $\mathrm{PM}_{10}$ ranged from 27 to $270 \mu \mathrm{g} / \mathrm{m}^{3}$ and from 30 to $276 \mu \mathrm{g} / \mathrm{m}^{3}$, respectively (Table $2 \mathrm{~S}$ ). Whilst for $\mathrm{PM}_{2.5}$ there was no significant difference with levels measured outdoors and in classrooms ( $71 \mathrm{vs} .82 \mu \mathrm{g} / \mathrm{m}^{3}, p=0.098$ ); for median $\mathrm{PM}_{10}$ indoor concentration was significantly higher than outdoor (75 vs. $127 \mu \mathrm{g} / \mathrm{m}^{3}, p=0.001$ ) (Table $2 \mathrm{~S}$ ). The indoor concentrations exceeded outdoor levels, leading to an I/O ratio higher than the unity, which suggests possible indoor sources (Table 3S).

The classrooms had a median concentration of bacteria higher than $1000 \mathrm{CFU} / \mathrm{m}^{3}$. In 35 (48\%) classrooms, indoor levels were higher than $3000 \mathrm{CFU} / \mathrm{m}^{3}$ (Table 1). There was a significant difference between indoor and outdoor levels of bacteria, being higher indoors (3224 CFU $/ \mathrm{m}^{3}$ vs. $213 \mathrm{CFU} / \mathrm{m}^{3}, p<0.01$ ) (Table $2 \mathrm{~S}$ ), with an $\mathrm{I} / \mathrm{O}$ ratio higher than the unit (Table $3 \mathrm{~S}$ ). Indoor fungi concentrations ranged from 61 to $1322 \mathrm{CFU} / \mathrm{m}^{3}$ (median $=240 \mathrm{CFU} / \mathrm{m}^{3}$ ). Although there were no significant differences between indoor and outdoor levels of fungi ( $240 \mathrm{CFU} / \mathrm{m}^{3}$ vs. $200 \mathrm{CFU} / \mathrm{m}^{3}, p=0.066$ ) (Table $2 \mathrm{~S}$ ) in $43 \%$ of classrooms the fungi levels were above the Portuguese legislation ("concentration of fungi indoors < concentration of fungi outdoors") (Ordinance 353-A/ 2013 of 4th December).

Carbon dioxide levels ranged widely and, among the 73 classrooms surveyed, $86 \%$ of the classrooms $(n=63)$ had median $\mathrm{CO}_{2}$ concentrations exceeding 1000 ppm (ASHRAE 62-2001, 2001). The $\mathrm{CO}_{2}$ levels changes in the classroom throughout the day and, depending on the occupancy and ventilation, following a path that is theoretically predictable for both the $\mathrm{CO}_{2}$ accumulation in the room during the time of teaching and for the $\mathrm{CO}_{2}$ reduction during the breaks. Maximum $\mathrm{CO}_{2}$ levels should be interpreted cautiously as they may reflect events such as occupants clustering around and/ or breathing on the sensor during occupancy. As expected, indoor $\mathrm{CO}_{2}$ levels were significantly higher than outdoor levels $(p<0.05)$ with an I/O ratio higher than 3 (Table $3 \mathrm{~S}$ ). Higher values were measured in classrooms with higher occupancy density for the longest teaching periods between breaks.

Table 2 and Table 3 shows data regarding the association of the indoor air parameters and wheeze, ever nasal allergy, cough episodes and phlegm episodes. After adjustment, higher values of toluene and o-xylene were associated with the occurrence of wheeze; no significant association was found with other VOC, but the increase concentration of TVOC showed increased odds of wheeze in the previous month. Acetaldehyde also showed a positive association with the occurrence of wheeze, but only concerning the previous year. In addition, higher exposure levels to $\mathrm{PM}_{2.5}$ and $\mathrm{PM}_{10}$ increase the odds of wheeze among children; being the association strong for $\mathrm{PM}_{10}$. Higher levels of bacteria showed increased odds of cough episodes but decreased odds of wheeze; 
Table 1

Summary statistics of indoor air parameters in classrooms ( $n=73$ classrooms).

\begin{tabular}{|c|c|c|c|c|c|}
\hline & Median & 25th percentile & 75th percentile & Minimum & Maximum \\
\hline Benzene, $\mu \mathrm{g} / \mathrm{m}^{3}$ & 2.5 & 1.6 & 2.6 & 1.5 & 2.7 \\
\hline Toluene, $\mu \mathrm{g} / \mathrm{m}^{3}$ & 6.4 & 4.5 & 10.4 & 1.8 & 202.5 \\
\hline $\mathrm{m} / \mathrm{p}$-xylene, $\mu \mathrm{g} / \mathrm{m}^{3}$ & 5.0 & 3.3 & 6.8 & 1.2 & 365.2 \\
\hline o-xylene, $\mu \mathrm{g} / \mathrm{m}^{3}$ & 2.3 & 1.8 & 3.8 & 1.1 & 52.4 \\
\hline $\mathrm{D}$-limonene, $\mu \mathrm{g} / \mathrm{m}^{3}$ & 23.1 & 11.5 & 48.6 & 2.8 & 215.3 \\
\hline$\alpha$-pinene, $\mu \mathrm{g} / \mathrm{m}^{3}$ & 1.8 & 1.3 & 2.8 & 1.0 & 32.0 \\
\hline $\mathrm{T} 3 \mathrm{CE}^{\mathrm{a}}, \mu \mathrm{g} / \mathrm{m}^{3}$ & - & - & - & - & - \\
\hline $\mathrm{T} 4 \mathrm{CE}^{\mathrm{b}}, \mu \mathrm{g} / \mathrm{m}^{3}$ & 2.9 & 1.8 & 3.4 & 1.1 & 8.3 \\
\hline Naphthalene, $\mu \mathrm{g} / \mathrm{m}^{3}$ & 1.3 & 1.2 & 1.6 & 1.2 & 1.7 \\
\hline Styrene, $\mu \mathrm{g} / \mathrm{m}^{3}$ & 1.2 & 1.2 & 1.4 & 1.0 & 2.7 \\
\hline TVOC $^{\mathrm{C}}, \mu \mathrm{g} / \mathrm{m}^{3}$ & 140.3 & 85.5 & 198.4 & 8.88 & 820.2 \\
\hline Formaldehyde, $\mu \mathrm{g} / \mathrm{m}^{3}$ & 17.5 & 13.8 & 23.1 & 8.24 & 126.9 \\
\hline Acetaldehyde, $\mu \mathrm{g} / \mathrm{m}^{3}$ & 7.7 & 5.0 & 10.4 & 1.9 & 64.6 \\
\hline $\mathrm{PM}_{2.5}, \mu \mathrm{g} / \mathrm{m}^{3}$ & 82 & 67 & 106 & 39 & 244 \\
\hline $\mathrm{PM}_{10}, \mu \mathrm{g} / \mathrm{m}^{3}$ & 127 & 109 & 167 & 56 & 320 \\
\hline Bacteria, CFU $/ \mathrm{m}^{3}$ & 3224 & 1784 & 5430 & 168 & 8372 \\
\hline Fungi, $\mathrm{CFU} / \mathrm{m}^{3}$ & 240 & 169 & 400 & 61 & 1322 \\
\hline $\mathrm{CO}_{2}, \mathrm{ppm}$ & 1469 & 1195 & 2104 & 829 & 3111 \\
\hline Temperature, ${ }^{\circ} \mathrm{C}$ & 20.8 & 19.2 & 21.7 & 14.3 & 24.6 \\
\hline Relative humidity, \% & 54 & 50 & 65 & 34 & 74 \\
\hline
\end{tabular}

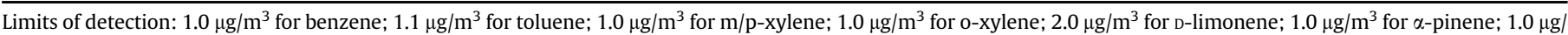
$\mathrm{m}^{3}$ for T3CE and T4CE; $1.0 \mu \mathrm{g} / \mathrm{m}^{3}$ for naphthalene and for styrene.

a Trichloroethylene.

b Tetrachloroethylene.

c Total Volatile Organic Compounds.

while higher concentrations of fungi also were associated with lower odds of wheeze.

Table 4 and Table 5 presents the results of lung function tests (percentage predicted of FVC, $\mathrm{FEV}_{1}, \mathrm{FEV}_{1} / \mathrm{FVC}$ ratio and $\mathrm{FEF}_{25-75 \%}$ ) found in the 761 children (392 girls) that underwent pulmonary function tests according to the categories of indoor air parameters. Generally, children present normal pulmonary function and although some statistical differences were found, no relevant differences were detected according to the levels of indoor air parameters.

To investigate the association between indoor air parameters and airway inflammation, the eNO test was used. Exhaled nitric oxide was assessed in 318 children (51.9\%), where $23.3 \%$ of schoolchildren had an eNO value over $20 \mathrm{ppb}$ and $10.7 \%$ presented values above $35 \mathrm{ppb}$.

Since eNO could be influenced by the presence of respiratory and allergic symptoms, we stratified our sample according the presence of acute respiratory symptoms (wheeze, sneeze, runny or blocked nose). Children with symptoms or disease diagnosed by a doctor ( $n=156)$ were defined based on an affirmative response to one of the following questions: "Has your child ever had wheezing or whistling in the chest at any time in the past?"; "In the past 12 months, has your child had wheezing or whistling in the chest?"; "In the past 30 days, has your child had wheezing or whistling in the chest?"; "Has your child ever had asthma diagnosed by a doctor?"; "Has your child ever had a problem with sneezing, or a runny, or blocked nose when he/she did not have a cold or the flu?"; "In the past 12 months, has your child had a problem with sneezing, or a runny, or blocked nose when he/she did not have a cold or the flu?"; "Has your child ever had nasal allergies, including hay fever?" and "If yes, was it confirmed by a physician?".

The global median (P25-P75) of eNO was $13.0 \mathrm{ppb}$ (9.00-18.0 ppb), being significantly lower among children without symptoms [12.0 ppb (9.00-17.0 ppb)] than in those with symptoms [13.5 ppb (10.0-23.0 ppb)], $p=0.021$.

Non-significant differences of eNO values were found according to indoor exposure among children without symptoms or disease diagnosed by a doctor. Among those with symptoms or disease diagnosed by a doctor increased levels of eNO were associated with increased levels of particles and the opposite was found regarding o-xylene, bacteria and fungi concentrations. However, none of the comparisons reach statistical significance (Table 6).

\section{Discussion}

The 73 classrooms monitored showed low levels of VOC, but often high levels of $\mathrm{PM}_{2.5}, \mathrm{PM}_{10}$, and bacterial concentrations. Total VOC levels measured in this study are higher than in previous studies [Smedje et al. (1997); Zhang et al. (2006); Godwin and Batterman (2007)], but lower than those measured by Yang et al. (2009); the concentrations of individual VOC are much lower than the recommended value proposed by EU-INDEX project (Kotzias et al., 2005) and WHO (2010). The observed D-limonene concentration range is much lower than the recommended limit value proposed by EU-INDEX project $\left(450 \mu \mathrm{g} / \mathrm{m}^{3}\right.$ ) (Kotzias et al., 2005). The presence of $D$-limonene was identified in both indoor and outdoor air samples but with higher concentrations in the indoor environment $(\mathrm{I} / \mathrm{O}>6)$ suggesting additional indoor sources or inadequate renovation of air indoors as suggested by the obtained $\mathrm{CO}_{2}$ levels (using school-day averages $86 \%$ of the classrooms had levels higher than $1000 \mathrm{ppm}$ ). Comparisons of VOC levels across studies can be difficult due to differences in definition, sampling times, measurement, and analysis (Zhang et al., 2006). In schools that have swimming pools, dedicated science and art classrooms, and so on, higher concentrations of certain VOC (e.g., chlorinated VOCs, aromatics) might be expected (Godwin and Batterman, 2007). According to Mendell (2007) and Zhang et al. (2006), VOC are likely originated from a combination of building sources, occupant activities, and outdoor sources. In addition to these indoor sources, the insufficient ventilation is likely to favour the increase of VOC levels.

The median values of formaldehyde levels were lower than the guidelines values established by the WHO (2010) $\left(100 \mu \mathrm{g} / \mathrm{m}^{3}\right.$, $30 \mathrm{~min}$ sampling time) and the EU-INDEX project $\left(30 \mu \mathrm{g} / \mathrm{m}^{3}\right.$, 30 min sampling time) (Kotzias et al., 2005). Indoor concentrations of formaldehyde and acetaldehyde exceeding the outdoor concentrations suggest that indoor sources are the most important contributors to the indoor levels. Indoor formaldehyde 
Table 2

Associations between volatile organic compounds and wheeze, nasal allergy, cough episodes and phlegm episodes $(n=978)$.

\begin{tabular}{|c|c|c|c|c|c|c|c|c|c|c|}
\hline & \multicolumn{2}{|c|}{ Wheeze (<12 months) } & \multicolumn{2}{|c|}{ Wheeze (<30 days) } & \multicolumn{2}{|c|}{ Ever nasal allergy } & \multicolumn{2}{|c|}{ Cough episodes } & \multicolumn{2}{|c|}{ Phlegm episodes } \\
\hline & OR $(95 \% \mathrm{CI})$ & aOR $(95 \% \mathrm{CI})$ & OR $(95 \% \mathrm{CI})$ & $\mathrm{aOR}(95 \% \mathrm{CI})$ & OR $(95 \% \mathrm{CI})$ & $\mathrm{aOR}(95 \% \mathrm{CI})$ & OR $(95 \% \mathrm{CI})$ & $\mathrm{aOR}(95 \% \mathrm{CI})$ & OR $(95 \% \mathrm{CI})$ & aOR $(95 \% \mathrm{CI})$ \\
\hline \multicolumn{11}{|l|}{ Toluene, $\mu \mathrm{g} / \mathrm{m}^{3}$} \\
\hline$<4.64$ & 1 & 1 & 1 & 1 & 1 & 1 & 1 & 1 & 1 & 1 \\
\hline \multirow[t]{2}{*}{$4.64-8.06$} & $1.29(0.78$ & $1.32(0.74$ & $0.84(0.38$ & $0.91(0.38$ & $1.03(0.68$ & $0.95(0.60$ & $0.83(0.52$ & $0.76(0.44$ & $0.82(0.50$ & $0.70(0.40$ \\
\hline & $-2.16)$ & $-2.35)$ & $-1.85)$ & $-2.14)$ & $-1.55)$ & $-1.51)$ & $-1.33)$ & $-1.31)$ & $-1.34)$ & $-1.21)$ \\
\hline$\geq 8.07$ & $\begin{array}{l}1.55(0.94 \\
-2.57)\end{array}$ & $\begin{array}{l}1.82(1.01 \\
-3.30)^{*}\end{array}$ & $\begin{array}{l}1.65(0.83 \\
-3.29)\end{array}$ & $\begin{array}{l}2.44(1.11 \\
-5.40)^{*}\end{array}$ & $\begin{array}{l}0.98(0.65 \\
-1.49)\end{array}$ & $\begin{array}{l}1.07(0.66 \\
-1.72)\end{array}$ & $\begin{array}{l}0.62(0.38 \\
-1.04)\end{array}$ & $\begin{array}{l}0.73(0.40 \\
-1.33)\end{array}$ & $\begin{array}{l}0.65(0.39 \\
-1.10)\end{array}$ & $\begin{array}{l}0.63(0.34 \\
-1.16)\end{array}$ \\
\hline \multicolumn{11}{|c|}{$\mathrm{m} / \mathrm{p}$-xylene, $\mu \mathrm{g} / \mathrm{m}^{3}$} \\
\hline$<4.02$ & 1 & 1 & 1 & 1 & 1 & 1 & 1 & 1 & 1 & 1 \\
\hline \multirow[t]{2}{*}{$4.02-5.89$} & $2.03(1.23$ & $2.35(1.32$ & $1.77(0.83$ & $2.13(0.92$ & $1.36(0.91$ & $1.37(0.88$ & $0.83(0.52$ & $0.87(0.49$ & $0.75(0.46$ & $0.78(0.45$ \\
\hline & $-3.36)^{*}$ & $-4.21)^{*}$ & $-3.77)$ & $-4.97)$ & $-2.03)$ & $-2.14)$ & $-1.35)$ & $-1.52)$ & $-1.23)$ & $-1.37)$ \\
\hline \multirow[t]{2}{*}{$\geq 5.90$} & $1.36(0.79$ & $1.84(0.96$ & $1.75(0.81$ & $2.32(0.94$ & $0.84(0.54$ & $0.88(0.52$ & $0.71(0.43$ & $0.94(0.51$ & $0.68(0.40$ & $0.70(0.38$ \\
\hline & $-2.33)$ & $-3.52)$ & $-3.76)$ & $-5.73)$ & $-1.30)$ & $-1.46)$ & $-1.17)$ & $-1.74)$ & $-1.13)$ & $-1.30)$ \\
\hline \multicolumn{11}{|c|}{ o-xylene, $\mu \mathrm{g} / \mathrm{m}^{3}$} \\
\hline$<1.89$ & 1 & 1 & 1 & 1 & 1 & 1 & 1 & 1 & 1 & 1 \\
\hline \multirow[t]{2}{*}{$1.89-2.61$} & $1.49(0.88$ & $1.62(0.89$ & $1.02(0.48$ & $1.55(0.63$ & $0.94(0.62$ & $0.84(0.52$ & $1.19(0.73$ & $1.27(0.70$ & $1.05(0.64$ & $1.02(0.57$ \\
\hline & $-2.42)$ & $-2.98)$ & $-2.17)$ & $-3.79)$ & $-1.41)$ & $-1.37)$ & $-1.92)$ & $-2.30)$ & $-1.72)$ & $-1.84)$ \\
\hline \multirow[t]{2}{*}{$\geq 2.62$} & $1.44(0.86$ & $1.66(0.92$ & $1.50(0.74$ & $2.27(1.01$ & $0.99(0.66$ & $0.95(0.60$ & $0.87(0.52$ & $0.92(0.50$ & $0.77(0.46$ & $0.76(0.41$ \\
\hline & $-2.39)$ & $-2.99)$ & $-3.02)$ & $-5.11)^{*}$ & $-1.49)$ & $-1.52)$ & $-1.45)$ & $-1.70)$ & $-1.31)$ & $-1.39)$ \\
\hline \multicolumn{11}{|c|}{ D-limonene, $\mu \mathrm{g} / \mathrm{m}^{3}$} \\
\hline$<12.19$ & 1 & 1 & 1 & 1 & 1 & 1 & 1 & 1 & 1 & 1 \\
\hline $12.19-30.49$ & $\begin{array}{l}0.98(0.60 \\
-1.59)\end{array}$ & $\begin{array}{l}1.04(0.59 \\
-1.84)\end{array}$ & $\begin{array}{l}1.04(0.52 \\
-2.10)\end{array}$ & $\begin{array}{l}1.04(0.48 \\
-2.28)\end{array}$ & $\begin{array}{l}1.23(0.82 \\
-1.84)\end{array}$ & $\begin{array}{l}1.31(0.82 \\
-2.10)\end{array}$ & $\begin{array}{l}1.66(1.02 \\
-2.70)^{*}\end{array}$ & $\begin{array}{l}2.49(1.35 \\
-4.59)^{*}\end{array}$ & $\begin{array}{l}1.42(0.87 \\
-2.34)\end{array}$ & $\begin{array}{l}1.92(1.06 \\
-3.47)^{*}\end{array}$ \\
\hline \multirow[t]{2}{*}{$\geq 30.50$} & $1.05(0.64$ & $1.01(0.52$ & $0.98(0.47$ & $0.98(0.38$ & $0.93(0.61$ & $1.03(0.59$ & $0.93(0.54$ & $1.62(0.76$ & $0.89(0.52$ & $1.10(0.53$ \\
\hline & $-1.71)$ & $-1.95)$ & $-2.01)$ & $-2.49)$ & $-1.43)$ & $-1.81)$ & $-1.61)$ & $-3.44)$ & $-1.55)$ & $-2.28)$ \\
\hline \multicolumn{11}{|c|}{$\alpha$-pinene, $\mu \mathrm{g} / \mathrm{m}^{3}$} \\
\hline$<1.00$ & 1 & 1 & 1 & 1 & 1 & 1 & 1 & 1 & 1 & 1 \\
\hline \multirow[t]{2}{*}{$\geq 1.00$} & $1.55(0.84$ & $1.82(0.92$ & $1.79(0.70$ & $2.63(0.91$ & $0.87(0.56$ & $1.00(0.61$ & $0.98(0.57$ & $0.92(0.51$ & $1.14(0.64$ & $1.17(0.62$ \\
\hline & $-2.84)$ & $-3.57)$ & $-4.58)$ & $-7.58)$ & $-1.35)$ & $-1.62)$ & $-1.68)$ & $-1.67)$ & $-2.03)$ & $-2.21)$ \\
\hline \multicolumn{11}{|l|}{ TVOC, $\mu \mathrm{g} / \mathrm{m}^{3}$} \\
\hline$<101.87$ & 1 & 1 & 1 & 1 & 1 & 1 & 1 & 1 & 1 & 1 \\
\hline 101.87 & $1.58(0.96$ & $1.67(0.93$ & $1.95(0.89$ & $2.56(1.05$ & $1.50(1.00$ & $1.65(1.05$ & $0.84(0.51$ & $0.73(0.40$ & $0.75(0.47$ & $0.71(0.39$ \\
\hline-189.93 & $-2.61)$ & $-3.00)$ & $-4.26)$ & $-6.25)^{*}$ & $-2.25)^{*}$ & $-2.62)^{*}$ & $-1.38)$ & $-1.32)$ & $-1.27)$ & $-1.29)$ \\
\hline \multirow{2}{*}{$\geq 189.94$} & $1.42(0.86$ & $1.64(0.94$ & $2.22(1.05$ & $2.67(1.15$ & $0.97(0.64$ & $1.06(0.67$ & $0.80(0.49$ & $0.88(0.52$ & $0.81(0.50$ & $0.85(0.50$ \\
\hline & $-2.32)$ & $-2.85)$ & $-4.67)^{*}$ & $-6.18)^{*}$ & $-1.48)$ & $-1.68)$ & $-1.29)$ & $-1.49)$ & $-1.32)$ & $-1.45)$ \\
\hline Formaldehyde, & $\mu \mathrm{g} / \mathrm{m}^{3}$ & & & & & & & & & \\
\hline$<14.92$ & 1 & 1 & 1 & 1 & 1 & 1 & 1 & 1 & 1 & 1 \\
\hline $14.92-20.13$ & $\begin{array}{l}1.65(1.02 \\
-2.67)^{*}\end{array}$ & $\begin{array}{l}2.11(1.20 \\
-3.68)^{*}\end{array}$ & $\begin{array}{l}1.51(0.79 \\
-2.91)\end{array}$ & $\begin{array}{l}2.02(0.95 \\
-4.29)\end{array}$ & $\begin{array}{l}1.02(0.68 \\
-1.54)\end{array}$ & $\begin{array}{l}1.08(0.68 \\
-1.74)\end{array}$ & $\begin{array}{l}0.95(0.58 \\
-1.56)\end{array}$ & $\begin{array}{l}0.95(0.54 \\
-1.70)\end{array}$ & $\begin{array}{l}0.92(0.56 \\
-1.52)\end{array}$ & $\begin{array}{l}0.90(0.51 \\
-1.61)\end{array}$ \\
\hline$\geq 20.14$ & $0.98(0.58$ & $1.12(0.56$ & $0.58(0.25$ & $0.83(0.30$ & $0.97(0.64$ & $0.98(0.57$ & $1.00(0.61$ & $0.95(0.48$ & $0.89(0.53$ & $0.66(0.33$ \\
\hline & $-1.68)$ & $-2.24)$ & $-1.34)$ & $-2.31)$ & $-1.48)$ & $-1.68)$ & $-1.64)$ & $-1.86)$ & $-1.49)$ & $-1.32)$ \\
\hline Acetaldehyde, $\mu$ & $\mathrm{lg} / \mathrm{m}^{3}$ & & & & & & & & & \\
\hline$<5.80$ & 1 & 1 & 1 & 1 & 1 & 1 & 1 & 1 & 1 & 1 \\
\hline $5.80-9.82$ & $1.34(0.80$ & $1.59(0.90$ & $1.59(0.76$ & $1.60(0.73$ & $0.88(0.59$ & $1.07(0.68$ & $0.92(0.56$ & $0.89(0.51$ & $0.83(0.50$ & $0.80(0.45$ \\
\hline & $-2.23)$ & $-2.81)$ & $-3.31)$ & $-3.52)$ & $-1.32)$ & $-1.68)$ & $-1.52)$ & $-1.56)$ & $-1.40)$ & $-1.42)$ \\
\hline$\geq 9.83$ & $1.60(0.97$ & $1.83(1.01$ & $1.46(0.69$ & $1.92(0.82$ & $0.89(0.59$ & $0.98(0.61$ & $1.02(0.62$ & $1.14(0.62$ & $1.09(0.66$ & $1.12(0.62$ \\
\hline & $-2.66)$ & $-3.33)^{*}$ & $-3.12)$ & $-4.48)$ & $-1.35)$ & $-1.59)$ & $-1.67)$ & $-2.07)$ & $-1.80)$ & $-2.02)$ \\
\hline
\end{tabular}


(considered statistically significant) for the item in bold.

concentrations may be related to insulating materials; parquet, particle board or plywood furniture containing formaldehydebased resins; and paints, cleaning and other consumer products used either in the didactic work or in the cleaning processes of the classrooms (Mendell, 2007; Gilbert et al., 2008). Taking into consideration that each classroom was equipped with standard plywood school furniture, and that currently no special care is taken regarding the household products used in the classrooms, a particular attention should be made regarding the selection of new furniture, cleaning, consumer and didactic products.

The indoor median concentration of $\mathrm{PM}_{2.5}$ and $\mathrm{PM}_{10}$ in all of the classrooms exceeded the $25 \mu \mathrm{g} / \mathrm{m}^{3}$ and $50 \mu \mathrm{g} / \mathrm{m}^{3}$ guideline value suggested by WHO air quality guidelines for a sampling period of $24 \mathrm{~h}$. The particulate matter concentrations measured in this study, in particular $\mathrm{PM}_{2.5}$ levels, were higher than in previous studies performed in Europe, e.g. (Stranger et al., 2007; Almeida et al., 2011; Canha et al., 2015). According to Canha et al. (2014), $\mathrm{PM}_{2.5}$ was studied in a Portuguese classrooms and the values were high $\left(100 \pm 71 \mu \mathrm{g} / \mathrm{m}^{3}\right)$ than those obtained in the current study. The authors pointed out to a high contribution of a specific indoor source that was a mixture of wood burning (for classroom heating), soil re-suspension and chalk. This could be the reason why $\mathrm{PM}_{10}$ is usually higher indoors than outdoors, while $\mathrm{PM}_{2.5}$ is usually more related with outdoor infiltration in indoors (Almeida et al., 2011). Re-suspension of coarse particles indoors resulting from occupant activities as well as the presence of other potential indoor sources of coarse particles were important factors to the increase $\mathrm{PM}_{10}$ concentrations indoors. Besides delayed deposition/settlement due induced turbulence created by occupant's movements and the reduced ventilation could also affect the dispersion of $\mathrm{PM}_{10}$, and so causing their accumulation indoors. The $\mathrm{PM}_{10}$ indoor concentration profiles showed peaks within the time slots when the studied classrooms were occupied (Madureira et al., 2012). Fromme et al. (2007) reported that high PM $_{10}$ levels in schools were correlated with less frequent cleaning and inefficient removal of deposited particles that consequently became re-suspended. This is 
Table 3

Associations between particulate matter, bacteria, fungi and carbon dioxide and wheeze, nasal allergy, cough episodes and phlegm episodes $(n=978)$.

\begin{tabular}{|c|c|c|c|c|c|c|c|c|c|c|}
\hline & \multicolumn{2}{|c|}{ Wheeze (<12 months) } & \multicolumn{2}{|c|}{ Wheeze (<30 days) } & \multicolumn{2}{|c|}{ Ever nasal allergy } & \multicolumn{2}{|c|}{ Cough episodes } & \multicolumn{2}{|c|}{ Phlegm episodes } \\
\hline & OR $(95 \% \mathrm{CI})$ & $\mathrm{aOR}(95 \% \mathrm{CI})$ & OR $(95 \% \mathrm{CI})$ & $\mathrm{aOR}(95 \% \mathrm{CI})$ & OR (95\% CI) & aOR $(95 \% \mathrm{CI})$ & OR (95\% CI) & aOR $(95 \% \mathrm{CI})$ & OR (95\% CI) & $\mathrm{aOR}(95 \% \mathrm{CI})$ \\
\hline \multicolumn{11}{|l|}{$\mathrm{PM}_{2.5}, \mu \mathrm{g} / \mathrm{m}^{3}$} \\
\hline$<72.53$ & 1 & 1 & 1 & 1 & 1 & 1 & 1 & 1 & 1 & 1 \\
\hline $72.53-97.92$ & $\begin{array}{l}1.35(0.81 \\
-2.26)\end{array}$ & $\begin{array}{l}1.72(0.96 \\
-3.08)\end{array}$ & $\begin{array}{l}1.44(0.64 \\
-3.22)\end{array}$ & $\begin{array}{l}1.44(0.62 \\
-3.39)\end{array}$ & $\begin{array}{l}1.15(0.77 \\
-1.71)\end{array}$ & $\begin{array}{l}1.25(0.81 \\
-1.92)\end{array}$ & $\begin{array}{l}0.94(0.56 \\
-1.56)\end{array}$ & $\begin{array}{l}1.18(0.66 \\
-2.09)\end{array}$ & $\begin{array}{l}0.97(0.58 \\
-1.62)\end{array}$ & $\begin{array}{l}1.11(0.63 \\
-1.96)\end{array}$ \\
\hline$\geq 97.93$ & $\begin{array}{l}1.48(0.88 \\
-2.48)\end{array}$ & $\begin{array}{l}1.90(1.04 \\
-3.45)^{*}\end{array}$ & $\begin{array}{l}2.20(1.02 \\
-4.74)^{*}\end{array}$ & $\begin{array}{l}2.28(1.00 \\
-5.18)^{*}\end{array}$ & $\begin{array}{l}0.79(0.51 \\
-1.22)\end{array}$ & $\begin{array}{l}0.73(0.45 \\
-1.19)\end{array}$ & $\begin{array}{l}1.26(0.77 \\
-2.07)\end{array}$ & $\begin{array}{l}1.44(0.81 \\
-2.56)\end{array}$ & $\begin{array}{l}1.08(0.64 \\
-1.81)\end{array}$ & $\begin{array}{l}1.25(0.70 \\
-2.23)\end{array}$ \\
\hline \multicolumn{11}{|l|}{$\mathrm{PM}_{10}, \mu \mathrm{g} / \mathrm{m}^{3}$} \\
\hline$<116.77$ & 1 & 1 & 1 & 1 & 1 & 1 & 1 & 1 & 1 & 1 \\
\hline 116.77 & $1.07(0.64$ & $1.23(0.66$ & $1.85(0.78$ & $1.58(0.61$ & $1.09(0.73$ & $1.24(0.79$ & $1.18(0.70$ & $1.19(0.65$ & $0.90(0.54$ & $0.89(0.49$ \\
\hline-137.88 & $-1.80)$ & $-2.27)$ & $-4.39)$ & $-4.09)$ & $-1.63)$ & $-1.95)$ & $-1.96)$ & $-2.18)$ & $-1.50)$ & $-1.61)$ \\
\hline$\geq 137.89$ & $\begin{array}{l}1.48(0.90 \\
-2.45)\end{array}$ & $\begin{array}{l}1.93(1.07 \\
-3.49)^{*}\end{array}$ & $\begin{array}{l}2.96(1.30 \\
-6.73)^{*}\end{array}$ & $\begin{array}{l}3.00(1.23 \\
-7.33)^{*}\end{array}$ & $\begin{array}{l}0.79(0.51 \\
-1.21)\end{array}$ & $\begin{array}{l}0.73(0.44 \\
-1.19)\end{array}$ & $\begin{array}{l}1.36(0.82 \\
-2.27)\end{array}$ & $\begin{array}{l}1.36(0.75 \\
-2.47)\end{array}$ & $\begin{array}{l}1.05(0.63 \\
-1.74)\end{array}$ & $\begin{array}{l}1.11(0.62 \\
-1.98)\end{array}$ \\
\hline \multicolumn{11}{|c|}{ Bacteria, $\mathrm{CFU} / \mathrm{m}^{3}$} \\
\hline$<2058$ & 1 & 1 & 1 & 1 & 1 & 1 & 1 & 1 & 1 & 1 \\
\hline $2058-3856$ & $\begin{array}{l}0.76(0.48 \\
-1.22)\end{array}$ & $\begin{array}{l}0.83(0.48 \\
-1.41)\end{array}$ & $\begin{array}{l}0.94(0.49 \\
-1.81)\end{array}$ & $\begin{array}{l}0.88(0.43 \\
-1.83)\end{array}$ & $\begin{array}{l}1.08(0.72 \\
-1.62)\end{array}$ & $\begin{array}{l}1.29(0.82 \\
-2.04)\end{array}$ & $\begin{array}{l}1.05(0.61 \\
-1.79)\end{array}$ & $\begin{array}{l}1.33(0.72 \\
-2.46)\end{array}$ & $\begin{array}{l}1.28(0.74 \\
-2.23)\end{array}$ & $\begin{array}{l}1.44(0.78 \\
-2.64)\end{array}$ \\
\hline$\geq 3857$ & $\begin{array}{l}0.61(0.37 \\
-1.01)\end{array}$ & $\begin{array}{l}0.51(0.28 \\
-0.92)^{*}\end{array}$ & $\begin{array}{l}0.54(0.25 \\
-1.15)\end{array}$ & $\begin{array}{l}0.52(0.22 \\
-1.19)\end{array}$ & $\begin{array}{l}0.73(0.47 \\
-1.12)\end{array}$ & $\begin{array}{l}0.72(0.44 \\
-1.19)\end{array}$ & $\begin{array}{l}1.59(0.96 \\
-2.62)\end{array}$ & $\begin{array}{l}1.88(1.03 \\
-3.43)^{*}\end{array}$ & $\begin{array}{l}1.73(1.02 \\
-2.94)\end{array}$ & $\begin{array}{l}1.65(0.90 \\
-3.02)\end{array}$ \\
\hline \multicolumn{11}{|l|}{ Fungi, $\mathrm{CFU} / \mathrm{m}^{3}$} \\
\hline$<199.67$ & 1 & 1 & 1 & 1 & 1 & 1 & 1 & 1 & 1 & 1 \\
\hline $199.67-320$ & $\begin{array}{l}0.99(0.62 \\
-1.60)\end{array}$ & $\begin{array}{l}0.87(0.50 \\
-1.51)\end{array}$ & $\begin{array}{l}0.79(0.41 \\
-1.53)\end{array}$ & $\begin{array}{l}0.89(0.42 \\
-1.89)\end{array}$ & $\begin{array}{l}1.39(0.92 \\
-2.18)\end{array}$ & $\begin{array}{l}1.54(0.96 \\
-2.47)\end{array}$ & $\begin{array}{l}1.32(0.80 \\
-2.17)\end{array}$ & $\begin{array}{l}1.39(0.78 \\
-2.47)\end{array}$ & $\begin{array}{l}1.34(0.81 \\
-2.24)\end{array}$ & $\begin{array}{l}1.20(0.68 \\
-2.14)\end{array}$ \\
\hline$\geq 321$ & $\begin{array}{l}0.63(0.37 \\
-1.06)\end{array}$ & $\begin{array}{l}0.57(0.32 \\
-1.01)\end{array}$ & $\begin{array}{l}0.36(0.16 \\
-0.83)^{*}\end{array}$ & $\begin{array}{l}0.38(0.16 \\
-0.91)^{*}\end{array}$ & $\begin{array}{l}1.14(0.74 \\
-1.75)\end{array}$ & $\begin{array}{l}1.20(0.75 \\
-1.93)\end{array}$ & $\begin{array}{l}0.99(0.58 \\
-1.66)\end{array}$ & $\begin{array}{l}0.87(0.48 \\
-1.58)\end{array}$ & $\begin{array}{l}0.95(0.55 \\
-1.64)\end{array}$ & $\begin{array}{l}0.78(0.42 \\
-1.41)\end{array}$ \\
\hline \multicolumn{11}{|l|}{$\mathrm{CO}_{2}, \mathrm{ppm}$} \\
\hline$<1299.87$ & 1 & 1 & 1 & 1 & 1 & 1 & 1 & 1 & 1 & 1 \\
\hline 1299.87 & $0.62(0.37$ & $0.68(0.36$ & $1.15(0.54$ & $1.49(0.64$ & $0.97(0.64$ & $1.25(0.76$ & $0.53(0.31$ & $0.51(0.28$ & $0.56(0.33$ & $0.50(0.27$ \\
\hline-1913.07 & $-1.06)$ & $-1.25)$ & $-2.47)$ & $-3.46)$ & $-1.48)$ & $-2.06)$ & $-0.88)^{*}$ & $-0.95)^{*}$ & $-0.96)^{*}$ & $-0.94)^{*}$ \\
\hline$\geq 1913.08$ & $\begin{array}{l}1.08(0.67 \\
-1.72)\end{array}$ & $\begin{array}{l}1.19(0.63 \\
-2.26)\end{array}$ & $\begin{array}{l}1.47(0.71 \\
-3.03)\end{array}$ & $\begin{array}{l}2.07(0.81 \\
-5.27)\end{array}$ & $\begin{array}{l}0.98(0.65 \\
-1.50)\end{array}$ & $\begin{array}{l}1.30(0.75 \\
-2.26)\end{array}$ & $\begin{array}{l}0.66(0.41 \\
-1.08)\end{array}$ & $\begin{array}{l}0.85(0.43 \\
-1.68)\end{array}$ & $\begin{array}{l}0.74(0.45 \\
-1.22)\end{array}$ & $\begin{array}{l}0.70(0.36 \\
-1.37)\end{array}$ \\
\hline
\end{tabular}

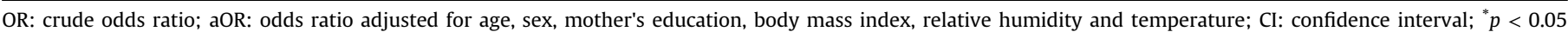
(considered statistically significant) for the item in bold.

Table 4

Spirometry parameters values according to indoor air volatile organic compounds.

\begin{tabular}{|c|c|c|c|c|c|c|c|c|c|c|c|c|}
\hline & \multicolumn{3}{|c|}{$\begin{array}{l}\text { FVC (\% of the predicted value) } \\
(n=761)\end{array}$} & \multicolumn{3}{|c|}{$\begin{array}{l}\mathrm{FEV}_{1}(\% \text { of the predicted value }) \\
(n=761)\end{array}$} & \multicolumn{3}{|c|}{$\mathrm{FEV}_{1} / \mathrm{FVC}(n=761)$} & \multicolumn{3}{|c|}{$\begin{array}{l}\mathrm{FEF}_{25-75}(\% \text { of the predicted } \\
\text { value) }(n=749)\end{array}$} \\
\hline & $n$ & Mean (SD) & $p$-value & $n$ & Mean (SD) & $p$-value & $n$ & Mean (SD) & $p$-value & $n$ & Mean (SD) & $p$-value \\
\hline Toluene, $\mu \mathrm{g} / \mathrm{m}^{3}$ & & & 0.689 & & & 0.377 & & & 0.293 & & & 0.103 \\
\hline$<4.64$ & 257 & $103.9(12.0)$ & & 257 & $107.2(11.1)$ & & 257 & $103.5(5.15)$ & & 254 & $108.9(18.2)$ & \\
\hline $4.64-8.06$ & 253 & $103.8(11.6)$ & & 253 & 108.5 (11.9) & & 253 & $104.7(5.35)$ & & 250 & $114.9(22.6)$ & \\
\hline$\geq 8.07$ & 243 & $102.4(12.4)$ & & 243 & $106.0(13.2)$ & & 243 & $103.6(6.61)$ & & 237 & $109.1(22.6)$ & \\
\hline $\mathrm{m} / \mathrm{p}$-xylene, $\mu \mathrm{g} / \mathrm{m}^{3}$ & & & 0.075 & & & 0.205 & & & 0.414 & & & 0.939 \\
\hline$<4.02$ & 249 & $104.4(11.6)$ & & 249 & $107.8(10.7)$ & & 249 & $103.5(5.46)$ & & 247 & $110.4(19.2)$ & \\
\hline $4.02-5.89$ & 261 & $104.6(11.7)$ & & 261 & $108.4(12.3)$ & & 261 & $103.8(5.77)$ & & 257 & $111.0(22.4)$ & \\
\hline$\geq 5.90$ & 243 & $100.9(14.4)$ & & 243 & $105.3(12.8)$ & & 243 & $104.6(5.82)$ & & 237 & $111.6(21.8)$ & \\
\hline o-xylene, $\mu \mathrm{g} / \mathrm{m} 3$ & & & 0.728 & & & 0.808 & & & 0.125 & & & 0.221 \\
\hline$<1.89$ & 250 & $104.2(11.8)$ & & 250 & $107.6(10.8)$ & & 250 & $103.5(5.51)$ & & 249 & $109.4(18.4)$ & \\
\hline $1.89-2.61$ & 247 & $102.8(12.2)$ & & 247 & $107.7(12.6)$ & & 247 & $104.9(5.17)$ & & 245 & $114.2(22.4)$ & \\
\hline$\geq 2.62$ & 256 & $103.3(12.0)$ & & 256 & $106.6(12.6)$ & & 256 & $103.4(6.27)$ & & 247 & $109.3(22.3)$ & \\
\hline D-limonene, $\mu \mathrm{g} / \mathrm{m}^{3}$ & & & 0.268 & & & 0.426 & & & 0.753 & & & 0.886 \\
\hline$<12.19$ & 254 & $104.8(12.8)$ & & 254 & $108.3(12.2)$ & & 254 & $103.6(5.52)$ & & 250 & $111.9(21.3)$ & \\
\hline $12.19-30.49$ & 257 & $103.3(11.7)$ & & 257 & $107.4(12.0)$ & & 257 & $104.1(4.89)$ & & 253 & $110.5(19.4)$ & \\
\hline$\geq 30.50$ & 242 & $107.8(11.0)$ & & 242 & $105.9(11.7)$ & & 242 & $104.2(6.78)$ & & 238 & $110.6(23.4)$ & \\
\hline$\alpha$-pinene, $\mu \mathrm{g} / \mathrm{m}^{3}$ & & & 0.459 & & & 0.601 & & & 0.640 & & & 0.903 \\
\hline$<1.00$ & 129 & $104.7(10.0)$ & & 129 & $108.2(9.80)$ & & 129 & $103.6(5.73)$ & & 128 & $111.4(19.5)$ & \\
\hline$\geq 1.00$ & 624 & $103.2(12.3)$ & & 624 & $107.1(12.4)$ & & 624 & $104.0(5.70)$ & & 613 & $111.0(21.6)$ & \\
\hline TVOC, $\mu \mathrm{g} / \mathrm{m}^{3}$ & & & 0.060 & & & $0.013^{*}$ & & & 0.534 & & & 0.158 \\
\hline$<101.87$ & 286 & $103.9(12.9)$ & & 286 & $108.1(12.3)$ & & 286 & $104.3(5.49)$ & & 283 & $112.8(20.7)$ & \\
\hline $101.87-189.93$ & 214 & $105.1(11.2)$ & & 214 & $109.2(11.7)$ & & 214 & $104.0(4.94)$ & & 210 & $112.4(22.2)$ & \\
\hline$\geq 189.94$ & 253 & $100.8(11.1)$ & & 253 & $103.9(11.5)$ & & 253 & $103.3(6.73)$ & & 248 & $107.0(20.6)$ & \\
\hline Formaldehyde, $\mu \mathrm{g} / \mathrm{m}^{3}$ & & & 0.855 & & & 0.370 & & & 0.213 & & & 0.281 \\
\hline$<14.92$ & 267 & $102.9(18.9)$ & & 267 & $106.2(10.8)$ & & 267 & $103.4(5.08)$ & & 266 & $108.6(20.7)$ & \\
\hline $14.92-20.13$ & 256 & $103.6(11.9)$ & & 256 & $107.1(11.7)$ & & 256 & $103.7(6.75)$ & & 253 & $111.4(21.0)$ & \\
\hline$\geq 20.14$ & 238 & $103.9(13.2)$ & & 238 & $108.7(13.5)$ & & 238 & $104.8(5.11)$ & & 230 & $113.7(21.8)$ & \\
\hline Acetaldehyde, $\mu \mathrm{g} / \mathrm{m}^{3}$ & & & 0.061 & & & $0.029^{*}$ & & & 0.471 & & & 0.432 \\
\hline$<5.80$ & 253 & $103.9(12.1)$ & & 253 & $107.1(11.3)$ & & 253 & $103.3(5.41)$ & & 251 & $109.3(19.4)$ & \\
\hline $5.80-9.82$ & 279 & $101.4(11.3)$ & & 279 & $105.3(11.9)$ & & 279 & $104.0(6.39)$ & & 273 & $110.7(22.3)$ & \\
\hline$\geq 9.83$ & 229 & $105.5(12.2)$ & & 229 & $110.0(12.4)$ & & 229 & $104.4(4.99)$ & & 225 & $113.6(21.5)$ & \\
\hline
\end{tabular}

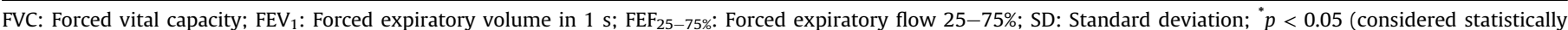
significant) for the item in bold. 
Table 5

Spirometry parameters values according to indoor particulate matter, bacteria, fungi and carbon dioxide.

\begin{tabular}{|c|c|c|c|c|c|c|c|c|c|c|c|c|}
\hline & \multicolumn{3}{|c|}{$\begin{array}{l}\text { FVC (\% of the predicted value) } \\
(n=761)\end{array}$} & \multicolumn{3}{|c|}{$\begin{array}{l}\mathrm{FEV}_{1}(\% \text { of the predicted value }) \\
(n=761)\end{array}$} & \multicolumn{3}{|c|}{$\mathrm{FEV}_{1} / \mathrm{FVC}(n=761)$} & \multicolumn{3}{|c|}{$\begin{array}{l}\mathrm{FEF}_{25-75}(\% \text { of the predicted } \\
\text { value) }(n=749)\end{array}$} \\
\hline & $n$ & Mean (SD) & $p$-value & $n$ & Mean (SD) & $p$-value & $n$ & Mean (SD) & $p$-value & $n$ & Mean (SD) & $p$-value \\
\hline $\mathrm{PM}_{2.5}, \mu \mathrm{g} / \mathrm{m}^{3}$ & & & 0.451 & & & 0.603 & & & 0.644 & & & 0.443 \\
\hline$<72.53$ & 224 & $102.2(13.5)$ & & 224 & $106.5(13.6)$ & & 224 & $104.4(5.31)$ & & 217 & $111.0(20.7)$ & \\
\hline $72.53-97.92$ & 269 & $104.5(11.2)$ & & 269 & $108.3(10.9)$ & & 269 & $103.9(5.80)$ & & 266 & $113.3(22.5)$ & \\
\hline$\geq 97.93$ & 262 & $103.5(11.4)$ & & 262 & $107.1(11.7)$ & & 262 & $103.6(5.91)$ & & 260 & $109.3(20.4)$ & \\
\hline $\mathrm{PM}_{10}, \mu \mathrm{g} / \mathrm{m}^{3}$ & & & 0.733 & & & 0.974 & & & 0.264 & & & 0.588 \\
\hline$<116.77$ & 230 & 102.5 (13.9) & & 230 & $107.2(13.8)$ & & 230 & $104.8(5.24)$ & & 222 & $112.0(21.9)$ & \\
\hline $116.77-137.88$ & 255 & $103.8(11.0)$ & & 255 & $107.6(10.7)$ & & 255 & $103.8(5.64)$ & & 254 & $112.3(21.1)$ & \\
\hline$\geq 137.89$ & 270 & $103.8(11.4)$ & & 270 & $107.2(11.8)$ & & 270 & $103.4(6.06)$ & & 267 & $109.4(21.0)$ & \\
\hline Bacteria, CFU $/ \mathrm{m}^{3}$ & & & 0.229 & & & $0.026^{*}$ & & & $0.032^{*}$ & & & $0.002^{*}$ \\
\hline$<2058.00$ & 233 & $101.8(10.4)$ & & 233 & $104.2(10.4)$ & & 233 & $102.6(5.36)$ & & 232 & $104.1(18.0)$ & \\
\hline $2058.00-3856.00$ & 260 & $104.9(12.7)$ & & 260 & $109.1(12.4)$ & & 260 & $104.3(6.34)$ & & 252 & $114.8(22.3)$ & \\
\hline$\geq 3857.00$ & 252 & $103.0(12.4)$ & & 252 & $107.8(12.5)$ & & 252 & $104.8(5.01)$ & & 249 & $113.4(21.3)$ & \\
\hline Fungi, CFU $/ \mathrm{m}^{3}$ & & & 0.200 & & & 0.268 & & & 0.762 & & & 0.747 \\
\hline$<199.67$ & 253 & $103.0(12.3)$ & & 253 & $106.6(12.5)$ & & 253 & $103.7(5.36)$ & & 251 & $109.6(22.2)$ & \\
\hline $199.67-320.00$ & 226 & $101.8(12.6)$ & & 226 & $106.0(13.0)$ & & 226 & $104.3(6.20)$ & & 224 & $111.6(22.7)$ & \\
\hline$\geq 321.00$ & 270 & $105.0(11.0)$ & & 270 & $108.8(10.5)$ & & 270 & $103.8(5.61)$ & & 262 & $111.7(18.8)$ & \\
\hline $\mathrm{CO}_{2}, \mathrm{ppm}$ & & & 0.745 & & & 0.801 & & & 0.692 & & & 0.717 \\
\hline$<1299.87$ & 242 & $104.0(10.4)$ & & 242 & 108.2 (9.79) & & 242 & $104.3(4.69)$ & & 242 & $112.7(17.5)$ & \\
\hline 1299.87-1913.07 & 243 & $102.0(14.0)$ & & 243 & $106.2(14.3)$ & & 243 & $104.3(6.08)$ & & 236 & $111.3(24.8)$ & \\
\hline$\geq 1913.08$ & 249 & $103.9(11.0)$ & & 249 & $107.4(11.6)$ & & 249 & $103.5(6.16)$ & & 245 & $109.6(20.8)$ & \\
\hline
\end{tabular}

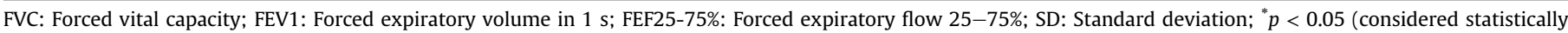
significant) for the item in bold.

consistent with the observations from other studies (Guo et al., 2010; Almeida et al., 2011; Oeder et al., 2012). Moreover, in Portugal, some studies already showed that there is a high contribution from the chalk used in the blackboards to the overall indoor $\mathrm{PM}_{10}$ and total suspended matter (Almeida et al., 2011; Canha et al., $2014)$. Due to the fact that $13(65 \%)$ of the schools in the present study were situated close $(<500 \mathrm{~m})$ to a heavily trafficked road and that $5(25 \%)$ were close $(<100 \mathrm{~m})$ to a car park it is expected that ambient air did contribute to indoor concentrations of particulate matter in the classrooms. This illustrates the potential impact of the location of schools, and it could therefore be suggested that when new schools are built, outdoor risks factors should be taken into account.

Mean indoor levels of bacteria higher than $500 \mathrm{CFU} / \mathrm{m}^{3}$ were observed in 63 (86\%) classrooms; which is similar to those obtained in 11 schools in Porto during the winter season (Madureira et al., 2009), but lower than those reported in a study covering 3 schools in Lisboa also in winter time (Pegas et al., 2010). Indoor bacteria concentrations are higher when compared with outdoor levels, indicating significant indoor sources and insufficient ventilation. One possible cause for this observation may be the higher occupancy and active behavioural pattern/activity level of children in relatively small spaces. This assertion is also supported by a number of previous studies in which human occupancy was found to affect indoor microbial concentrations, as settled spores were resuspended by human activities (e.g. walking and running in indoor sites) (Kim et al., 2007; Mentese et al., 2009). In addition these findings might also be due to poor ventilation taking into account that all schools are naturally ventilated as reported previously by Canha et al. (2013). Another possible explanation is the environmental conditions surrounding the buildings, as plants and soil outdoors; as well as the influence of season (winter time) and climate.

For both the indoor and outdoor air samples, the concentrations of fungi are lower than the concentrations of the bacteria, which are consistent with other studies (Godwin and Batterman, 2007). As the measurements were taken between November 2011 and March 2012, and between November and December 2012, the weather conditions included low outdoor temperatures $\left(14.6 \pm 3.3^{\circ} \mathrm{C}\right)$ and moderate precipitation levels, which may explain the lower outdoor concentrations. However, during the heating season, occupants generally spend more time in indoor environments, windows are more often closed and ventilation may be insufficient; thus, indoor temperature and relative humidity become suitable for fungal growth indoors. Indoor fungal growth is mainly affected by their outdoor concentration and indoor factors such, as temperature, humidity and building/furnishing materials (Meng et al., 2012). Indoor bioaerosol concentrations can be highly variable and influenced by many factors, e.g. the life cycle of the organism, season, humidity and window opening. Thus, the short-term bioaerosol samples reflect concentrations only for the day the samples were taken and may not be representative of long-term exposures.

In the present study, TVOC exposure levels were significantly associated with wheeze in the preceding month and were also related to increments in reported ever nasal allergy. Therefore, it can be supposed that TVOC may be associated with the presence of asthma or allergic rhinitis, although for the latter no nose symptoms were reported and the 3rd tertile of TVOC concentrations may reject the hypothesis of allergic rhinitis. Total VOC concentration was related to chronic airway and chronic eye symptoms by Hulin et al. (2010). Concerning spirometry, all parameters in the volume of exhaled air were lower where TVOC had higher concentrations (highest tertile), being statistically significant for $\mathrm{FEV}_{1}$. The eNO results support the potential existence of chronic airway inflammation in children under medium TVOC exposure. In addition, eNO concentrations are significantly higher in children with symptoms of respiratory and allergic diseases when exposed to same TVOC concentrations as occurred with the remaining indoor air parameters. The potential mechanism of allergic sensitization could be the irritation properties of VOC. Volatile organic compounds could facilitate the penetration of allergens in the target organs by irritation of the respiratory mucosa and impaired muco-ciliary clearance (D' Amato et al., 2005). One of the molecular mechanisms that may explain the effects of indoor pollutants on inflammation is oxidative stress in which VOC may play a key role (Baeza and Marano, 2007; Bonay and Aubier, 2007). Another potential mechanism is a synergistic effect of sensitization and exposure to such pollutants on airway reactivity, lowering the dose of antigen 
Table 6

Exhaled nitric oxide values according to indoor air parameters.

\begin{tabular}{|c|c|c|c|c|c|c|}
\hline & \multicolumn{6}{|c|}{ eNO, ppb } \\
\hline & \multicolumn{3}{|c|}{$\begin{array}{l}\text { Children without } \\
\text { symptoms or disease }^{a} \\
(n=159)\end{array}$} & \multicolumn{3}{|c|}{$\begin{array}{l}\text { Children with symptoms } \\
\text { or disease }^{\mathrm{a}}(n=156)\end{array}$} \\
\hline & $n$ & Mean (SD) & $p$-value & $n$ & Mean (SD) & $p$-value \\
\hline Toluene, $\mu \mathrm{g} / \mathrm{m}^{3}$ & & & 0.626 & & & 0.474 \\
\hline$<4.64$ & 53 & $15.7(19.8)$ & & 56 & $19.5(18.4)$ & \\
\hline $4.64-8.06$ & 60 & $13.4(5.93)$ & & 50 & $23.4(20.5)$ & \\
\hline$\geq 8.07$ & 43 & 14.6 (7.69) & & 48 & $23.8(21.7)$ & \\
\hline $\mathrm{m} / \overline{\mathrm{p}}$-xylene, $\mu \mathrm{g} / \mathrm{m}^{3}$ & & & 0.144 & & & 0.202 \\
\hline$<4.02$ & 53 & $12.9(5.97)$ & & 48 & $21.1(18.9)$ & \\
\hline $4.02-5.89$ & 59 & $17.1(19.2)$ & & 59 & $25.6(22.8)$ & \\
\hline$\geq 5.90$ & 44 & $12.9(5.49)$ & & 47 & $18.7(20.1)$ & \\
\hline o-xylene, $\mu \mathrm{g} / \mathrm{m}^{3}$ & & & 0.507 & & & 0.725 \\
\hline$<1.89$ & 56 & 14.1 (6.39) & & 48 & $23.7(21.3)$ & \\
\hline $1.89-2.61$ & 56 & $13.4(6.78)$ & & 50 & $22.3(21.5)$ & \\
\hline$\geq 2.62$ & 44 & $16.3(21.6)$ & & 56 & 20.5 (17.9) & \\
\hline D-limonene, $\mu \mathrm{g} / \mathrm{m}^{3}$ & & & 0.926 & & & 0.841 \\
\hline$<12.19$ & 63 & $14.7(18.6)$ & & 49 & $21.6(18.4)$ & \\
\hline $12.19-30.49$ & 51 & $14.8(6.03)$ & & 57 & $23.3(21.5)$ & \\
\hline$\geq 30.50$ & 42 & $13.8(6.90)$ & & 48 & $21.1(20.4)$ & \\
\hline$\alpha$-pinene, $\mu \mathrm{g} / \mathrm{m}^{3}$ & & & 0.731 & & & 0.622 \\
\hline$<1.00$ & 24 & $13.7(5.61)$ & & 26 & $20.3(16.8)$ & \\
\hline$\geq 1.00$ & 132 & $14.6(13.6)$ & & 128 & $22.4(20.8)$ & \\
\hline TVOC, $\mu \mathrm{g} / \mathrm{m}^{3}$ & & & 0.158 & & & $0.012^{*}$ \\
\hline$<101.87$ & 64 & $13.5(6.82)$ & & 56 & $18.8(16.7)$ & \\
\hline $101.87-189.93$ & 45 & $17.6(21.5)$ & & 52 & $28.8(24.8)$ & \\
\hline$\geq 189.94$ & 47 & $13.0(5.21)$ & & 46 & $18.6(16.3)$ & \\
\hline Formaldehyde, $\mu \mathrm{g} / \mathrm{m}^{3}$ & & & 0.193 & & & 0.061 \\
\hline$<14.92$ & 58 & $13.4(4.99)$ & & 56 & $24.8(22.7)$ & \\
\hline $14.92-20.13$ & 48 & $17.4(20.8)$ & & 55 & $24.4(20.2)$ & \\
\hline$\geq 20.14$ & 53 & $13.4(7.56)$ & & 45 & $16.2(15.0)$ & \\
\hline Acetaldehyde, $\mu \mathrm{g} / \mathrm{m}^{3}$ & & & 0.354 & & & 0.358 \\
\hline$<5.80$ & 53 & $12.9(4.73)$ & & 52 & $25.4(22.4)$ & \\
\hline $5.80-9.82$ & 55 & $16.40(19.4)$ & & 57 & $20.3(17.9)$ & \\
\hline$\geq 9.83$ & 51 & $14.4(8.32)$ & & 47 & $20.8(19.8)$ & \\
\hline $\mathrm{PM}_{2.5}, \mu \mathrm{g} / \mathrm{m}^{3}$ & & & 0.212 & & & 0.210 \\
\hline$<72.53$ & 51 & $17.0(20.6)$ & & 46 & $19.6(16.9)$ & \\
\hline $72.53-97.92$ & 53 & $12.7(4.74)$ & & 58 & $20.8(19.3)$ & \\
\hline$\geq 97.93$ & 53 & $14.1(6.78)$ & & 50 & $26.4(23.5)$ & \\
\hline $\mathrm{PM}_{10}, \mu \mathrm{g} / \mathrm{m}^{3}$ & & & 0.430 & & & 0.165 \\
\hline$<116.77$ & 51 & $16.5(20.7)$ & & 48 & $18.9(18.3)$ & \\
\hline $116.77-137.88$ & 53 & $13.4(4.72)$ & & 55 & $21.4(18.4)$ & \\
\hline$\geq 137.89$ & 53 & $14.0(6.92)$ & & 51 & $26.4(23.2)$ & \\
\hline Bacteria, CFU $/ \mathrm{m}^{3}$ & & & 0.432 & & & 0.060 \\
\hline$<2058.00$ & 49 & $12.8(5.49)$ & & 49 & $27.6(23.0)$ & \\
\hline $2058.00-3856.00$ & 54 & $16.1(19.6)$ & & 55 & $21.1(19.0)$ & \\
\hline$\geq 3857.00$ & 54 & $14.9(7.81)$ & & 49 & $18.1(17.7)$ & \\
\hline Fungi, $\mathrm{CFU} / \mathrm{m}^{3}$ & & & 0.881 & & & 0.645 \\
\hline$<199.67$ & 51 & $14.2(5.58)$ & & 52 & $24.3(22.1)$ & \\
\hline $199.67-320.00$ & 49 & $14.2(7.36)$ & & 51 & $22.1(21.0)$ & \\
\hline$\geq 321.00$ & 58 & $15.2(19.2)$ & & 50 & $20.6(17.5)$ & \\
\hline $\mathrm{CO}_{2}, \mathrm{ppm}$ & & & 0.466 & & & 0.369 \\
\hline$<1299.87$ & 55 & $13.4(5.34)$ & & 51 & $25.1(20.1)$ & \\
\hline $1299.87-1913.07$ & 55 & $16.2(19.5)$ & & 53 & $19.5(18.6)$ & \\
\hline$\geq 1913.08$ & 43 & $14.0(7.40)$ & & 50 & $21.9(21.7)$ & \\
\hline
\end{tabular}

SD: Standard deviation; ${ }^{a}$ Disease diagnosed by a doctor; ${ }^{*} p<0.05$ (considered statistically significant) for the item in bold. Note: Kruskal-Wallis test was used to compare eNO values and indoor air parameters.

exposition needed to provoke bronchial or nasal constriction (Roux et al., 1999; Leikauf, 2002). Given the potential impact of exposure to VOC on children's health, it is important to increase the understanding of the factors that affect their indoor concentration. According to Mendell (2007) and Zhang et al. (2006), indoor TVOC levels might be due to the furnishing, floor covering, insulating materials, adhesives, paints and glues as well as other solvents and cleaning products. In addition to these indoor sources, the insufficient ventilation is likely to favour the increase of TVOC levels (Zhang et al., 2006) underlining the importance of occupant behaviours in the control and guarantee of healthy indoor air.
Formaldehyde is one of the most studied pollutants when focussing on the effect on indoor air pollution on respiratory health. According to Mendell (2007), recent epidemiological studies confirm the allergic potential of formaldehyde in the development of asthma and other allergic symptoms. A recent meta-analysis focussing on formaldehyde exposure and asthma in children calculated a pooled OR of 1.03 (95\% CI: 1.02-1.04) for an increase of $10 \mu \mathrm{g} / \mathrm{m}^{3}$ (McGwin et al., 2010). Two studies focused on respiratory effects of indoor formaldehyde exposure revealed an increased risk of asthma associated with elevated indoor concentrations (Smedje and Norbäck, 2001; Rumchev et al., 2002). In the present study, it was found that indoor exposure to formaldehyde was related to asthma-like symptoms, namely, wheeze in the past year and irritating cough reported during the previous 3 months. However, Ezratty et al. (2007) and Billionnet et al. (2011) questioned the effect of formaldehyde on asthma. As suggested by Wolkoff and Nielsen (2010), complex co-exposures with other compounds, exposure levels and socio-economic factors could encumber the interpretation of the association with formaldehyde, explaining different findings among studies. Acetaldehyde was also found to be associated with asthma-like symptoms in our population. In agreement with our findings, exposure to acetaldehyde at home, in a subsample of the 6 Cities study, was associated with a higher risk of asthma (Hulin et al., 2010). So far, few studies have assessed the effects of school indoor air parameters on children health using clinical objective measurements (Kim et al., 2007; Zhao et al., 2008; Le Cann et al., 2011; Martins et al., 2012). In the specific case of the present study, no associations were obtained between specific aldehydes and the inflammatory indicator eNO. Therefore, in light of the evidence that the variations in eNO measurements show some inconsistencies in children exposed to environmental pollutants, further research appears to be needed.

An increasing number of data has shown that increased levels of $\mathrm{PM}_{2.5}$ and $\mathrm{PM}_{10}$ should result in the increased prevalence of acute and chronic health effects, including asthma, among children (Daisey et al., 2003; Mendell and Heath, 2005). Links between health and $\mathrm{PM}_{2.5}$ concentrations were published for schoolyards and for classrooms (Annesi-Maesano et al., 2012). The present study showed that higher levels of $\mathrm{PM}_{2.5}$ and $\mathrm{PM}_{10}$ increase the odds of asthma-like symptoms (wheeze and irritating cough) among children; nevertheless the association was stronger for $\mathrm{PM}_{10}$. However, for the irritating cough this relationship disappears when the children with "feeling like getting a cold" are excluded. Annesi-Maesano et al. (2012) reported that high prevalence of asthma in the past year was found in children attending classrooms with $\mathrm{PM}_{2.5}$ levels higher than $17.5 \mu \mathrm{g} / \mathrm{m}^{3}$. It was also reported that increased $\mathrm{PM}_{10}$ concentrations had significant pertinence on lung disorders (such as wheeze and shortness of breath) and on reduction of lung functions; while $\mathrm{PM}_{2.5}$ were strongly associated with cardiopulmonary diseases and lung cancer (Gemenetzis et al., 2006). In addition, spirometry did not reveal an obstructive pattern. Nevertheless, given the association between wheeze symptoms, $\mathrm{PM}_{2.5}$ and $\mathrm{PM}_{10}$ levels, as well as the eNO results that, although not significant, were higher in the 3rd tertile among the children with symptoms or disease diagnosed by a doctor, it is possible to point out that particulate matter is associated with an increase in airways inflammation. Most studies of particulate matter have been focused on ambient (outdoor) exposures and their relationship to hospital admissions and mortality (Jaakkola et al., 2000). Although the mechanisms are not well understood, it has been shown that particulate matter may enhance airway inflammatory reactions and sensitization (Jaakkola et al., 2000). It has been suggested that this could be due to the intervention of the polycyclic aromatic hydrocarbon contained in particulate matter or strongly related to it. However, it cannot be excluded that 
particulate matter might also influence non-immunological properties of the allergens, such as their enzymatic activity, thus contributing to their increased penetration in the target organs (Steerenberg et al., 2003). Since the classrooms do not contain any specific $\mathrm{PM}_{2.5}$ source (such as smoking, cooking), the indoor $\mathrm{PM}_{2.5}$ concentrations were more likely to be due to outdoor penetration rather than indoor sources related to the presence of children and the intensity of their indoor activities as reported by Polidori et al. (2007); as well as resulted from reactions between ozone and terpenes (Sarwar et al., 2003; Weschler and Shields, 2003).

Regarding the exposure to indoor biological agents and after adjustment, lower odds of wheeze in the previous year were found among those in schools with higher levels of bacteria and of wheeze in the previous month among those in schools with higher levels of fungi. By contrast, higher levels of bacteria were significantly associated with higher odds of cough episodes. This is in contrast with a previous school study reporting positive associations between indoor viable bacteria measured in spring and current asthma (wheeze in the past 12 months) (Smedje et al., 1997) as well as with exacerbation of asthma (Douwes et al., 2003). Similarly, the findings of most epidemiological studies on bacterial components (such as endotoxin) have been contradictory (Radon, 2006). Some demonstrated protective effects, while others showed associations with increased asthma symptoms in children (Michel et al., 1996; Michel, 2000). In addition, despite the fact that spirometry parameters in general showed little variation, it was still possible to verify a significant difference in $\mathrm{FEF}_{25-75 \%}$ which was lower with higher levels of bacteria. The association between the concentrations of bacteria and the eNO results was more pronounced in children with symptoms of respiratory and allergic disease than in asymptomatic children, although the difference was not significant. According to Mendell et al. (2011), quantitatively determined concentrations of microbiological agents do not show a consistent association with respiratory health outcomes; in some cases, exposure to microbial factors is protective against asthma-related symptoms and wheezing, particularly for those who are exposed very early in life (Mendell et al., 2011). The inconsistent association between exposure to bacteria/fungi and health outcomes in different studies could in part be due to variations in study design, sampling and analysing method, season of the year for the measurements, region where the measurements have been made, climate and indoor activities, etc. (Ren et al., 2001; Chew et al., 2003). Additionally, the culture method has been criticised because of the short-term sampling of the measurement, which could not effectively represent the timeaveraged conditions experienced by children (Pasanen, 2001). There are also limitations in culture-based sampling methods for characterizing health-related bioaerosol composition and concentration indoors (Pasanen, 2001). However, several fungi produce allergens known to be associated with allergies and asthma; many fungi also produce toxins and irritants with suspected effects on respiratory health (WHO, 2009). Stark et al. (2005) noted that total fungi concentrations would group diverse genera into a single exposure variable that may not accurately predict risk. In addition, Holme et al. (2010) found no significant association between fungi concentrations and health outcomes despite the significant associations with specific genera. Fungi species of Penicillium, Aspergillus and Cladosporium have been the most frequently associated with allergy and exist both in indoor and outdoor environments (Daisey et al., 2003; Jo and Seo, 2005). This could imply that measurements of specific genera predict health outcomes better than viable fungi concentrations. Several aspects of this study are noteworthy as strengths. This study provides an IAQ investigation in a larger number of classrooms of public primary schools located in Porto and collected detailed information on health, based on questionnaire and clinical tests, of a susceptible population. In addition, measurements were performed for a broad spectrum of chemical, physical and biological agents in classrooms allowed a better appraisal of individual exposure compared to indirect methods such as the exclusive use of questionnaires or checklists (Viegi et al., 2004). Moreover, detailed health data on a large number of children (participation rate of about $70 \%$ ) were collected in the questionnaire study. Additionally, the use of different objective clinical outcomes is also a point that should be emphasised.

Because of the cross-sectional design of the study, the findings do not allow causal relationships between indoor air parameters and health outcomes. Although indoor air measurements were avoided during vacations or weekends and the school staff and teachers were asked not to modify their activities and behaviour during the survey to reduce misclassification, the measurement conducted during a single week may be a poor surrogate for past months/year exposure. Furthermore, one problem is selection bias, when i.e. parents of allergic children might be more willing to respond to questionnaires focussing on asthma and allergy compared with parents of nonallergic children (Bornehag et al., 2012). Furthermore, parents of children with allergies may also answer systematically differently compared with parents of children without allergy i.e. reporting bias. Another limitation may be associated with a minor contribution from the outdoor and home air exposure to the development of asthma-related symptoms. Also, the statistical analysis was performed using a 2 level factorial designs (child$\leftarrow$ classroom) and not 3 levels (child $\leftarrow$ classroom $\leftarrow$ school). Minimizing all these potential biases and, as well, increasing the response rates are known ways to obtain good data quality in questionnaire studies (Morton et al., 2006). Although the participation rate of $69.2 \%$ was reasonably high, the possibility of selection bias should still be considered.

This study contributes with new information on school environments in Portugal and their relationship with children health. This knowledge will be useful to develop appropriate control strategies and, thus, to limit exposures that may cause or contribute to asthma, allergy and other respiratory symptoms in children.

\section{Conclusions}

This work conducted a comprehensive characterization of a vast array of indoor air pollutants in 73 classrooms and investigates its relationship with respiratory symptoms among children aged 8-10 years. The exposure levels for the most indoor air parameters in the schools in the current study are in accordance with IAQ guidelines/ recommendations, except for particulate matter and bioaerosols; however exposure to indoor air pollutants, especially higher levels of TVOC, $\mathrm{PM}_{2.5}$ and $\mathrm{PM}_{10}$, could increase self-reported respiratory symptoms among children.

Children exposed to higher TVOC concentrations had a twofold increased risk of having asthma-related symptoms. These findings were supported by the results of spirometry and eNO tests which suggested the existence of chronic airway inflammation. Moreover, higher $\mathrm{PM}_{2.5}$ and $\mathrm{PM}_{10}$ levels increase the odds of asthma-like symptoms, with stronger association for $\mathrm{PM}_{10}$. The present study supports the pro-inflammatory role of $\mathrm{PM}_{2.5}$ and $\mathrm{PM}_{10}$, especially among more susceptible children.

Taking into account the unique characteristics of the public primary schools, such as large number of children who are more susceptible to air pollutants, time spend indoors, higher density of occupation - there is a need to develop appropriate control strategies to minimize the adverse health effects on children, teachers and school staff. 


\section{Acknowledgements}

This work was supported by ARIA Project PTDC/DTP-SAP/1522/ 2012 from Foundation for Science and Technology (Fundação para a Ciência e Tecnologia - FCT) co-financed by European Regional Development Fund through Operational Competitiveness Programme (COMPETE) FCOMP -01-0124-FEDER-028797; and by the Portuguese CCDR-N for funding the research project "E2BE" (NORTE-07-0124- FEDER-000036), through the European Union FEDER programme.

\section{Appendix A. Supplementary material}

Supplementary material related to this article can be found at http://dx.doi.org/10.1016/j.atmosenv.2015.07.028.

\section{References}

Almeida, S.M., Canha, N., Silva, A., Freitas, M. d. C., Pegas, P., Alves, C., Evtyugina, M., Pio, C.A., 2011. Children exposure to atmospheric particles in indoor of Lisbon primary schools. Atmos. Environ. 45 (40), 7594-7599.

American Society of Heating Refrigeration and Air Conditioning Engineers, 2001 ASHRAE 62-2011 Ventilation for Acceptable Indoor Air Quality.

American Thoracic Society, 1995. Standardization of spirometry - 1994 update. Am. J. Resp. Crit. Care 152 (3), 1107-1136.

American Thoracic Society; European Respiratory Society, 2005. ATS/ERS recommendations for standardized procedures for the online and offline measurement of exhaled lower respiratory nitric oxide and nasal nitric oxide, 2005. Am. J. Resp. Crit. Care 171 (8), 912-930.

Andersen, A., 1958. New sampler for the collection, sizing, and enumeration of viable airborne particles. J. Bacteriol. 76 (5), 471-484.

Annesi-Maesano, I., Baiz, N., Banerjee, S., Rudnai, P., Rive, S., The Sinphonie, G., 2013 Indoor air quality and sources in schools and related health effects. J. Toxicol. Environ. Health B 16 (8), 491-550.

Annesi-Maesano, I., Lavaud, F., Raherison, C., Kopferschmitt, C., Blay, F. d. Charpin, D., Caillaud, D., 2012. Poor air quality in classrooms related to asthma and rhinitis in primary schoolchildren of the French 6 Cities Study. Thorax 67 (8), 682-688.

Asher, M.I., Anderson, H.R., Stewart, A.W., Crane, J., Ait-Khaled, N., Anabwani, G., Anderson, H.R., Beasley, R., Bjorksten, B., Burr, M.L., Clayton, T.O., Ellwood, P. Keil, U., Lai, C.K.W., Mallol, J., Martinez, F.D., Mitchell, E.A., Montefort, S. Pearce, N., Robertson, C.F., Shah, J.R., Sibbald, B., Strachan, D.P., von Mutius, E. Weiland, S.K., Williams, H.C., ISAAC Steering Committee, 1998. Worldwide variations in the prevalence of asthma symptoms: the International Study of Asthma and Allergies in Childhood (ISAAC). Eur. Respir. J. 12 (2), 315-335.

Baeza, A., Marano, F., 2007. Air pollution and respiratory diseases: a central role for oxidative stress. Med. Sci. Paris. 23 (5), 497-501.

Bantz, S.K., Zhu, Z., Zheng, T., 2014. The atopic march: progression from atopic dermatitis to allergic rhinitis and asthma. J. Clin. Cell Immunol. 5 (2).

Billionnet, C., Gay, E., Kirchner, S., Leynaert, B., Annesi-Maesano, I., 2011. Quantitative assessments of indoor air pollution and respiratory health in a populationbased sample of French dwellings. Environ. Res. 111 (3), 425-434.

Bluyssen, P., 2014. The Healthy Indoor Environment: How to Assess Occupants Wellbeing in Buildings. In: Routledge (Ed.).

Bonay, M., Aubier, M., 2007. Air pollution and allergic airway diseases. Med. Sci. Paris. 23 (2), 187-192.

Bornehag, C.G., Moniruzzaman, S., Larsson, M., Lindstrom, C.B., Hasselgren, M., Bodin, A., von Kobyletzkic, L.B., Carlstedt, F., Lundin, F., Nanberg, E. Jonsson, B.A., Sigsgaard, T., Janson, S., 2012. The SELMA study: a birth cohort study in Sweden following more than 2000 mother-13 child pairs. Paediatr. Perinat. Epidemiol. 26, 456-467.

Canha, N., Almeida, S.M., Freitas, M.C. Taubel, M., Hanninen, O., 2013, Winte ventilation rates at primary schools: comparison between Portugal and Finland. J. Toxicol. Environ. Health-Part a-Curr. Issues 76 (6), 400-408.

Canha, N., Almeida, S.M., Freitas, M.D., Trancoso, M., Sousa, A., Mouro, F. Wolterbeek, H.T., 2014. Particulate matter analysis in indoor environments of urban and rural primary schools using passive sampling methodology. Atmos. Environ. 83, 21-34.

Canha, N., Mandin, C., Ramalho, O., Wyart, G., Riberon, J., Dassonville, C., Hanninen, O., Almeida, S.M., Derbez, M., 2015. Assessment of ventilation and indoor air pollutants in nursery and elementary schools in France. Indoor Air. http://dx.doi.org/10.1111/ina.12222.

Chew, G.L., Rogers, C., Burge, H.A., Muilenberg, M.L., Gold, D.R., 2003. Dustborne and airborne fungal propagules represent a different spectrum of fungi with differing relations to home characteristics. Allergy 58 (1), 13-20.

Clausen, G., Toftum, J., Bekö, G., 2009. Indoor Environment and Children's Health (IECH) - an ongoing epidemiological investigation on the association between indoor environmental factors in homes and kindergartens and children's health and wellbeing. In: Paper read at 9th International Healthy Building at Syracuse,
NY.

D'Amato, G., Liccardi, G., D' Amato, M., Holgate, S., 2005. Environmental risk factors and allergic bronchial asthma. Clin. Exp. Allergy 35 (9), 1113-1124.

Daisey, J.M., Angell, W.J., Apte, M.G., 2003. Indoor air quality, ventilation and health symptoms in schools: an analysis of existing information. Indoor Air 13, 53-64.

Direção-Geral de Estatísticas da Educação e Ciência. Educação em números, Portugal 2012 2014. Available from: https://educar.files.wordpress.com/2014/ 09/cneturmas.jpg.

Douwes, J., Thorne, P., Pearce, N., Heederik, D., 2003. Bioaerosol health effects and exposure assessment: progress and prospects. Ann. Occup. Hyg. 47 (3), $187-200$.

European Standards, 2000. CSN EN 13098-Workplace Atmosphere - Guidelines for Measurement of Airborne Micro-organisms and Endotoxin.

Ezratty, V., Bonay, M., Neukirch, C., Orset-Guillossou, G., Dehoux, M., Koscielny, S., Cabanes, P.A., Lambrozo, J., Aubier, M., 2007. Effect of formaldehyde on asthmatic response to inhaled allergen challenge. Environ. Health Perspect. 115, 210-214.

Falcão, H., Ramos, E., Marques, A., Barros, H., 2008. Prevalence of asthma and rhinitis in 13 year old adolescents in Porto, Portugal. Rev. Port. Pneumol. 14 (6), $747-768$.

Fromme, H., Twardella, D., Dietrich, S., Heitmann, D., Schierl, R., Liebl, B., Ruden, H., 2007. Particulate matter in the indoor air of classrooms -- exploratory results from Munich and surrounding area. Atmos. Environ. 41 (4), 854-866.

Gemenetzis, P., Moussas, P., Arditsoglou, A., Samara, C., 2006. Mass concentration and elemental composition of indoor PM2.5 and PM10 in university rooms in Thessaloniki, northern Greece. Atmos. Environ. 40 (17), 3195-3206.

Gilbert, N.L., Guay, M., Gauvin, D., Dietz, R.N., Chan, C.C., Levesque, B., 2008. Air change rate and concentration of formaldehyde in residential indoor air. Atmos. Environ. 42 (10), 2424-2428.

Godwin, C., Batterman, S., 2007. Indoor air quality in Michigan schools. Indoor Air 17 (2), 109-121.

Guo, H., Morawska, L., He, C., Zhang, Y.L., Ayoko, G., Cao, M., 2010. Characterization of particle number concentrations and PM2.5 in a school: influence of outdoor air pollution on indoor air. Environ. Sci. Pollut. Res. Int. 17, 1268-1278.

Hatziagorou, E., Tsanakas, J., 2007. Assessment of airway inflammation with exhaled NO measurement. Hippokratia 11 (2), 51-62.

Holme, J., Hägerhed-Engman, L., Mattsson, J., Sundell, J., Bornehag, C., 2010. Culturable mold in indoor air and its association with moisture-related problems and asthma and allergy among Swedish children. Indoor Air 20 (4), 329-340.

Hulin, M., Caillaud, D., Annesi-Maesano, I., 2010. Indoor air pollution and childhood asthma: variations between urban and rural areas. Indoor Air 20 (6), 502-514.

ISO 4833:2013, 2013. Microbiology of the Food Chain - Horizontal Method for the Enumeration of Microorganisms - Part 1: Colony Count at 30 Degrees C by the Pour Plate Technique. International Standard Organization.

ISO 16000-1:2004, 2004. Indoor Air - Part 1: General Aspects of Sampling Strategy. International Standard Organization.

ISO 16000-4:2011, 2011. Determination of Formaldehyde - Diffusive Sampling Method. International Standard Organization.

ISO 16000-6:2011, 2011. Determination of Volatile Organic Compounds in Indoor and Test Chamber Air by Active Sampling on Tenax TA Sorbent, Thermal Desorption and Gas Chromatography Using MS or MS-FID. International Standard Organization.

Jaakkola, J., Verkasalo, P., Jaakkola, N., 2000. Plastic wall materials in the home and respiratory health in young children. Am. J. Public Health 90 (5), 797-799.

Jo, W.K., Seo, Y.J., 2005. Indoor and outdoor bioaerosol levels at recreation facilities, elementary schools, and homes. Chemosphere 61 (11), 1570-1579.

Kim, J.L., Elfman, L., Mi, Y., Wieslander, G., Smedje, G., Norbäck, D., 2007. Indoor molds, bacteria, microbial volatile organic compounds and plasticizers in schools-associations with asthma and respiratory symptoms in pupils. Indoor Air 17 (2), 153-163.

Kotzias, D., Koistinen, K., Kephalopoulos, S., Schlitt, C., Carrer, P., Maroni, M., Jantunen, M., Cochet, C., Kirchner, S., Lindvall, T., McLaughlin, J., Molhave, L. Fernandes, E.O., Seifert, B., 2005. The INDEX Project. Critical Appraisal of the Setting and Implementation of Indoor Exposure Limits in the EU. Final Report. EUR 21590 EN. European Comission, Directorate General, Joint Research Centre.

Le Cann, P., Bonvallot, N., Glorennec, P., Deguen, S., Goeury, C., Le Bot, B., 2011. Indoor environment and children's health: recent developments in chemical, biological, physical and social aspects. Int. J. Hyg. Environ. Health 215, 1-18.

Leikauf, G.D., 2002. Hazardous air pollutants and asthma. Environ. Health Perspect. 110 (Suppl. 4), 505-526.

Lotvall, J., Ekerljung, L., Ronmark, E., Wennergren, G., Linden, A., Ronmark, E., 2009. West Sweden Asthma Study: prevalence trends over the last 18 years argues no recent increase in asthma. Respir. Res. 10, 94.

Madureira, J., Alvim-Ferraz, M.C.M., Rodrigues, S., Goncalves, C., Azevedo, M.C., Pinto, E., Mayan, O., 2009. Indoor air quality in schools and health symptoms among Portuguese teachers. Hum. Ecol. Risk Assess. 15 (1), 159-169.

Madureira, J., Paciencia, I., Oliveira Fernandes, E., 2012. Levels and indoor-outdoor relationships of size-specific particulate matter in naturally ventilated Portuguese schools. J. Toxicol. Environ. Health A 75 (22-23), 1423-1436.

Martins, P.C., Valente, J., Papoila, A.L., Caires, I., Araujo-Martins, J., Mata, P., Lopes, M., Torres, S., Rosado-Pinto, J., Borrego, C., Annesi-Maesano, I., Neuparth, N., 2012. Airways changes related to air pollution exposure in wheezing children. Eur. Resp. J. 39 (2), 246-253.

Masoli, M., Fabian, D., Holt, S., Beasley, R., 2004. The global burden of asthma: executive summary of the GINA Dissemination Committee report. Allergy 59 (5), 
469-478.

McGwin, G., Lienert, J., Kennedy, J.I., 2010. Formaldehyde exposure and asthma in children: a systematic review. Environ. Health Perspect. 118 (3), 313-317.

Mendell, M., Mirer, A., Cheung, K., 2011. Respiratory and allergic health effects of dampness, mold, and dampness-related agents: a review of the epidemiologic evidence. Environ. Health Respect. 119, 748-756.

Mendell, M.J., 2007. Indoor residential chemical emissions as risk factors forrespiratory and allergic effects in children: a review. Indoor Air 17 (4), 259-277.

Mendell, M.J., Heath, G.A., 2005. Do indoor pollutants and thermal conditions in schools influence student performance? A critical review of the literature. Indoor Air 15 (1), 27-52.

Meng, J., Barnes, C.S., Rosenwasser, L.J., 2012. Identity of the fungal species present in the homes of asthmatic children. Clin. Exp. Allergy 42 (10) 1448-1458.

Mentese, S., Arisoy, M., Rad, A.Y., Gullu, G., 2009. Bacteria and fungi levels in various indoor and outdoor environments in Ankara, Turkey. Clean-Soil, Air Water 37, 487-493.

Michel, O., 2000. Systemic and local airways inflammatory response to endotoxin. Toxicology 152 (1-3), 25-30.

Michel, O., Kips, J., Duchateau, J., Vertongen, F., Robert, L., Collet, H., Pauwels, R., Sergysels, R., 1996. Severity of asthma is related to endotoxin in house dust. Am. J. Respir. Crit. Care Med. 154 (6), 1641-1646.

Miller, M.R., Hankinson, J., Brusasco, V., Burgos, F., Casaburi, R., Coates, A., Crapo, R. Enright, P. van der Grinten, C.P., Gustafsson, P. Jensen, R. Johnson, D.C. MacIntyre, N., McKay, R., Navajas, D., Pedersen, O.F., Pellegrino, R., Viegi, G., Wanger, J., 2005. Standardisation of spirometry. Eur. Respir. J. 26 (2), 319-338. Mortimer, K.M., Fallot, A., Balmes, J.R., Tager, I.B., 2003. Evaluating the use of a portable spirometer in a study of pediatric asthma. Chest 123 (6), 1899-1907.

Morton, L.M., Cahill, J., Hartge, P., 2006. Reporting participation in epidemiologic studies: a survey of practice. Am. J. Epidemiol. 163, 197-203.

NIOSH., 1998. NIOSH Manual of Analytical Methods.

Oeder, S., Dietrich, S., Weichenmeier, I., Schober, W., Pusch, G., Jorres, R.A., Schierl, R., Nowak, D., Fromme, H., Behrendt, H., Buters, J.T., 2012. Toxicity and elemental composition of particulate matter from outdoor and indoor air of elementary schools in Munich, Germany. Indoor Air 22 (2), 148-158.

Oliveira Fernandes, E., Gustafsson, H., Seppänen, O., Crump, D., Ventura Silva, G., 2008. WP3 Final Report on Characterization of Spaces and Sources. EnVIE Project. European Commission 6th Framework Programme of Research, Brussels.

Ordinance 353-A/2013 of 4th December, 2013. Diário da República, 1.a série, No. 235. Ministry of Environment, Territory Planning, Health and Solidarity, Employment and Social Security, Lisbon, Portugal.

Pasanen, A.L., 2001. A review: fungal exposure assessment in indoor environments. Indoor Air 11 (2), 87-98.

Pearce, N., Douwes, J., Beasley, R., 2000. The rise and rise of asthma: a new paradigm for the new millennium? J. Epidemiol. Biostat. 5 (1), 5-16.

Pegas, P.N., 2012. Qualidade do ar interior em escolas do $1^{\circ}$ ciclo de Lisboa e Aveiro, Universidade de Aveiro, Aveiro.

Pegas, P.N., Evtyugina, M.G., Alves, C.A., Nunes, T., Cerqueira, M., Franchi, M., Pio, C., Almeida, S.M., Freitas, M.D., 2010. Outdoor/indoor air quality in primary schools in Lisbon: a preliminary study. Quimica Nova 33 (5), 1145-1149.

Polidori, A., Arhami, M., Sioutas, C., Delfino, R.J., Allen, R., 2007. Indoor/outdoor relationships, trends, and carbonaceous content of fine particulate matter in retirement homes of the Los Angeles basin. J. Air Waste Manag. Assoc. 57 (3), $366-379$.

Prieto, L., 2002. Measurement of exhaled nitric oxide concentrations in asthma. Technical aspects and clinical usefulness. Alergol. Inmunol. Clin. 17, 72-87.

Radon, K., 2006. The two sides of the "endotoxin coin”. Occup. Environ. Med. 63 (1),
$73-78,10$.

Ren, P., Jankun, T.M., Belanger, K., Bracken, M.B., Leaderer, B.P., 2001. The relation between fungal propagules in indoor air and home characteristics. Allergy 56 (5), 419-424.

Roux, E., Hyvelin, J.M., Savineau, J.P., Marthan, R., 1999. Human isolated airway contraction: interaction between air pollutants and passive sensitization. Am. J. Respir. Crit. Care Med. 160 (2), 439-445.

Rumchev, K.B., Spickett, J.T., Bulsara, M.K., Phillips, M.R., Stick, S.M., 2002. Domestic exposure to formaldehyde significantly increases the risk of asthma in young children. Eur. Respir. J. 20 (2), 403-408.

Sarwar, G., Corsi, R., Allen, D., Weschler, C., 2003. The significance of secondary organic aerosol formation and growth in buildings: experimental and computational evidence. Atmos. Environ. 37 (9-10), 1365-1381.

Simoni, M., Annesi-Maesano, I., Sigsgaard, T., Norbäck, D., Wieslander, G. Nystad, W., Canciani, M., Sestini, P., Viegi, G., 2010. School air quality related to dry cough, rhinitis and nasal patency in children. Eur. Respir. J. 35 (4), 742-749.

Smedje, G., Norbäck, D., 2001. Incidence of asthma diagnosis and selfreported allergy in relation to the school environment-a four-year follow-up study in schoolchildren. Int. J. Tuberc. Lung Dis. 5, 1059-1066.

Smedje, G., Norbäck, D., Edling, C., 1997. Subjective indoor air quality in schools in relation to exposure. Indoor Air 7, 143-150.

Stark, P.C., Celedon, J.C., Chew, G.L., Ryan, L.M., Burge, H.A., Muilenberg, M.L., Gold, D.R., 2005. Fungal levels in the home and allergic rhinitis by 5 years of age. Environ. Health Perspect. 113 (10), 1405-1409.

Steerenberg, P.A., Withagen, C.E.T., Dormans, J.A.M.A., van Dalen, W.J., van Loveren, H., Casee, F.R., 2003. Adjuvant activity of various diesel exhaust and ambient particles in two allergic models. J. Toxicol. Env. Heal. A 66 (15), 1421-1439.

Stranger, M., Potgieter-Vermaak, S.S., Van Grieken, R., 2007. Comparative overview of indoor air quality in Antwerp, Belgium. Environ. Int. 33 (6), 789-797.

Viegi, G., Simoni, M., Scognamiglio, A., Baldacci, S., Pistelli, F., Carrozzi, L., AnnesiMaesano, I., 2004. Indoor air pollution and airway disease. Int. J. Tuberc. Lung D. 8 (12), 1401-1415.

Weschler, C.J., Shields, H.C., 2003. Experiments probing the influence of air exchange rates on secondary organic aerosols derived from indoor chemistry. Atmos. Environ. 37 (39-40), 5621-5631.

Wolkoff, P., Nielsen, G.D., 2010. Non-cancer effects of formaldehyde and relevance for setting an indoor air guideline. Environ. Int. 36 (7), 788-799.

World Health Organization, 2005. Air Quality Guidelines Global Update 2005 Particulate Matter, Ozone, Nitrogen Dioxide and Sulfur Dioxide.

World Health Organization, 2007. Global Surveillance, Prevention and Control of Chronic Respiratory Diseases - a Comprehensive Approach. Geneva.

World Health Organization, 2009. Dampness and Mould. WHO guidelines for indoor air quality.

World Health Organization, 2010. In: World Health Organization Regional Office for Europe (Ed.), WHO Guidelines for Indoor Air Quality: Selected Pollutants. Copenhagen.

Yang, W., Sohn, J., Kim, J., Son, B., Park, J., 2009. Indoor air quality investigation according to age of the school buildings in Korea. J. Environ. Manag. 90 (1) $348-354$.

Zhang, G. Spickett, J., Rumchev, K., Lee, A.H., Stick, S., 2006. Indoor environmenta quality in a 'low allergen' school and three standard primary schools in Western Australia. Indoor Air 16, 74-80.

Zhao, Z.H., Zhang, Z., Wang, Z.H., Ferm, M., Liang, Y.L., Norbäck, D., 2008. Asthmatic symptoms among pupils in relation to winter indoor and outdoor air pollution in schools in Taiyuan, China. Environ. Health Perspect. 116 (1), 90-97. 